DRILLING AND GEOHYDROLOGIC DATA FOR

TEST HOLE USW UZ-1, YUCCA MOUNTAIN, NYE COUNTY, NEVADA

By M.S. Whitfield, William Thordarson, and D.P. Hammermeister,

U.S. Geological Survey, and J.B. Warner, Ecology and Environment, Inc.

(formerly with Fenix \& Scisson, Inc.)

U.S. GEOLOGICAL SURVEY

Open-File Report 90-354

Prepared in cooperation with the

NEVADA OPERATIONS OFFICE,

U.S. DEPARTMENT OF ENERGY, under

Interagency Agreement DE-AI08-78ET44802

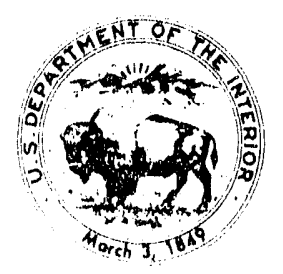

Denver, Colorado

1990

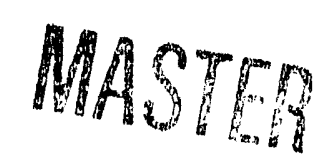

DOTRIBUTOR OF THIS DOKUIMTNT IS UNLIMITED 


\section{U.S. DEPARTMENT OF THE INTERIOR}

MANUEL LUJAN, JR., Secretary

U.S. GEOLOGICAL SURVEY

Dallas L. Peck, Director

For additional information write to:

Chief, Yucca Mountain Project Branch U.S. Geological Survey Box 25046, Mail Stop 421 Denver Federa: Center Denver, CO 80225-0046
Copies of this report can be purchased from:

U.S. Geological Survev Books and Open-File Reports Section Federal Center Box 25425

Denver, CO 80225-0425 


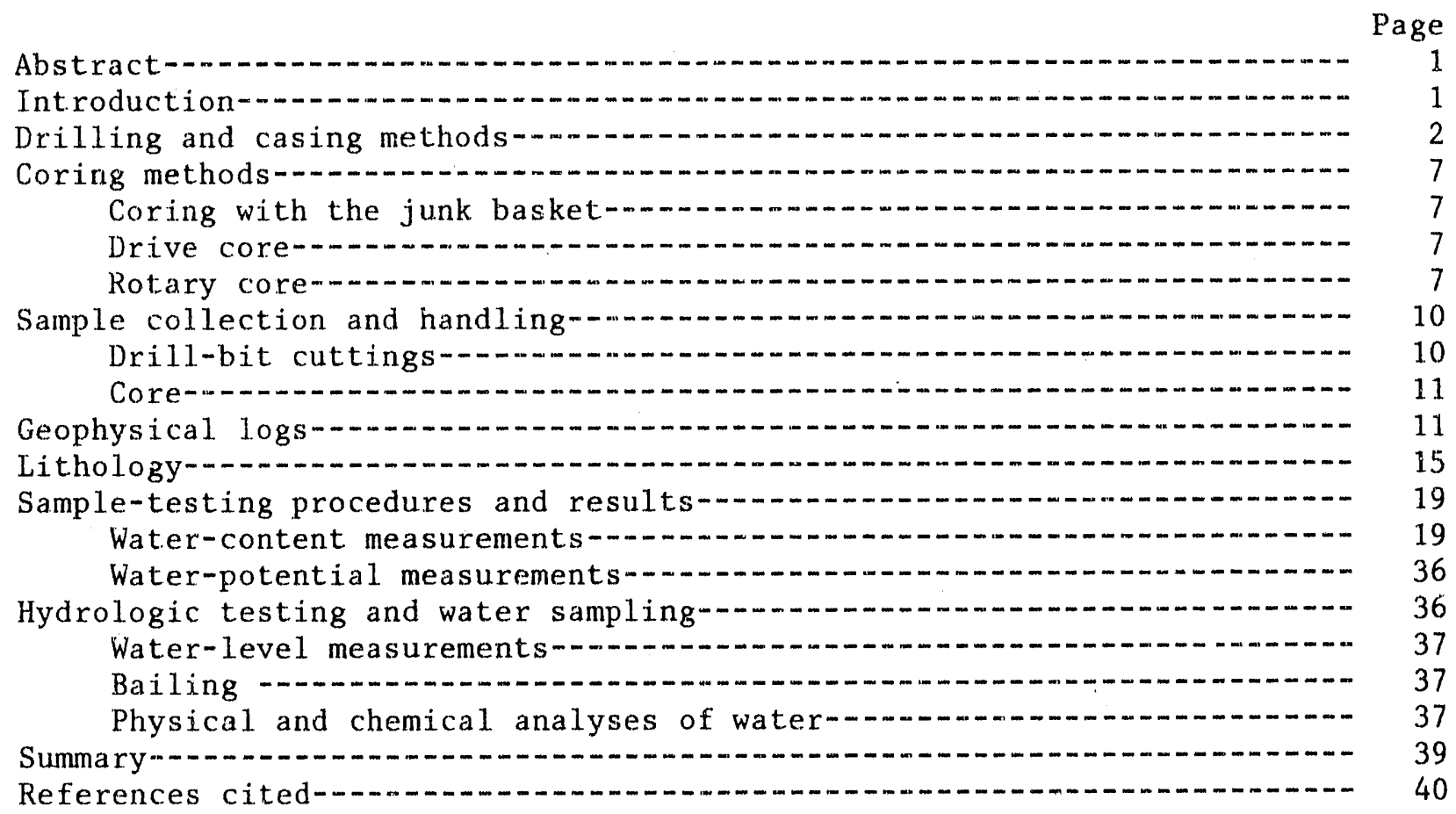

FIGURES

Figure 1. Map showing location of test hole USW UZ-1, nearby test holes, and geographic features-

2. Schematic diagram of separators, vacuum unit, and exhaust muffler- 4

3. Graph showing drilling rate and borehole deviation from depths of: $A, 0$ to 200.0 meters; and $B, 200.0$ to 382.5 meters

4. Rose diagram showing strikes of fractures- 15

5. Graph showing water content of drill-bit cuttings from depths of: $A, 0$ to 100.6 meters; $B, 100.6$ to 201.2 meters; $C, 201.2$ to 301.8 meters; and $D, 301.8$ to 382.5 meters $-\cdots$ 
Table 1. Bit, casing, and cementing data-1. Page

2. Cored intervals (Globe junk basket)

3. Geophysical logs obtained in the borehole

4. Out-of-gage borehole intervals-ar. 13

5. Percentage of out-of-gage borehole for stratigraphic units penetrated-14

6. Fracture distribution observed using a downhole television

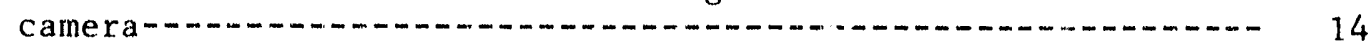

7. Lithologic log of drill-bit cuttings

8. Results of laboratory analyses for hydrologic properties of drill-bit cuttings-1.... 20

9. Water-level measurements-1. 38

10. Analytical results for water sample-38

\section{CONVERSION FACTORS}

Metric (International System) units used in this report may be converted to inch-pound units by using the following conversion factors:

\begin{tabular}{lcl}
\multicolumn{1}{c}{ Multiply } & $B y$ & \multicolumn{1}{c}{ To obtain } \\
centimeter $(\mathrm{cm})$ & 0.3937 & inch \\
cubic centimeter & & \\
per minute $\left(\mathrm{cm}^{3} / \mathrm{min}\right)$ & 0.06102 & cubic inches per minute \\
cubic meter $\left(\mathrm{m}^{3}\right)$ & 35.315 & cubic feet \\
gram (g) & 0.03527 & ounce \\
kilometer $(\mathrm{km})$ & 0.6214 & mile \\
kilopascals $(\mathrm{kPa})$ & 0.1450 & pounds per square inch \\
liter (L) & 0.2642 & gallon \\
liter per second $(\mathrm{L} / \mathrm{s})$ & 15.85 & gallon per minute \\
meter (m) & 3.281 & foot \\
millimeter $(\mathrm{mm})$ & 0.03937 & inch
\end{tabular}

Degree Celsius $\left({ }^{\circ} \mathrm{C}\right)$ may be converted to degree Fahrenheit $\left({ }^{\circ} \mathrm{F}\right)$ by using the following equation:

$$
{ }^{\circ} \mathrm{F}=9 / 5 \quad\left({ }^{\circ} \mathrm{C}\right)+32 \text {. }
$$

The following terms and abbreviations also are used in this report:

milligram per liter $(\mathrm{mg} / \mathrm{L})$

micrometer $(\mu \mathrm{m})$

microvolts $(\mu \mathrm{V})$

Sea level: In this report "sea level" refers to the National Geodetic Vertical Datum of 1929 (NGVD of 1929)--a geodetic datum derived from a general adjustment of the first-order level nets of both the United States and Canada, formerly called Sea Level Datum of 1929. 


\title{
DRILLING AND GEOHYDROLOGIC DATA FOR TEST HOLE USW UZ-1, YUCCA MOUNTAIN, NYE COUNTY, NEVADA
}

By M.S. Whitfield, Willian Thordarson, D.P. Hammermeister, and J.B. Warner.

\begin{abstract}
ABS'TRAC'T
This report presents data collected to determine the hydrologic characteristics of tuffaceous rocks penetrated in test hole USW UZ-1. The borehole is the first of two deep, large-diameter, unsaturated-zone test holes dry drilled using the vacuum/reverse-air-circulation method. This test hole was drilled in and near the southwestern part of the Nevada Test Site, Nye County, Nevada, in a program conducted in cooperation with the U.S. Department of Energy. These investigations are part of the Yucca Mountain Project (formerly the Nevada Nuclea waste Storage Investigations) to identify a potentially suitable site for the storage of high-level radioactive wastes.

Data are presented for bit and casing configurations, coring methods, sample collection, drilling rate, borehole deviation, and out-of-gage borehole. Geologic data for this borehole include geophysical logs, a lithologic log of drill-bit cuttings, and strike and distribution of fractures. Hydrologic data include water-content and water-potential measurements of drill-bit cuttings, water-leve? measurement: chemical analyses of water: Laboratory measurements of moisture content and matric properties from the larger drill-bit cutting fragments were considered to be representative of in-situ conditions.
\end{abstract}

\section{INTRODUCTION}

The U.S. Geological Survey has been conducting investigations at Yucca Mountain, Nevada, to evaluate the hydrologic and geologic suitability of this site for storing high-level nuclear waste in an underground mined repository. These investigations are part of the Yucca Mountain Project conducted in cooperation with the U.S. Department of Energy, Nevada Operations Office. Test drilling has been a principal method of investigation. This report presents borehole, geologic, and hydrologic data for test hule USW UZ-1, the first of two deep, large-diameter (444 mm), unsaturated-zone test holes dry drilled into tuff in or near the southwestern part of the Nevada Test Site using the vacuum/reverse-air-circulation drilling method.

The primary objectives in drilling test hole USW UZ-1 were to: (1) Obtain a vertical. moisture-content profile of the rocks drilled; (2) check for the presence of perched-water zones; and (3) emplace hydrologic instruments at selected depths so that a long-term record of pressure and moisturemptential data could be collected. The unsaturated section in the Yucca Mountain area consists of nonwelded to densely welded tuff ranging in thickness from 457 to $762 \mathrm{~m}$. 
Test hole USW UZ-1 is located in Nye County, about $140 \mathrm{~km}$ northwest of Las Vegas in the southern part of the State (fig. 1). The drill site is in Drill Hole Wash, a southeasterly draining canyon of Yucca Mountain northwest of Jackass Flats (fig. 1). The test hole is about $9 \mathrm{~km}$ northwest of watersupply well J-13 and is at Nevada State Central Zone Coordinates N. 771,276, E. 560,221 . The test hole is about $0.3 \mathrm{~km}$ northwest of test hole USW G-1; the test hole is about $0.7 \mathrm{~km}$ west-northwest of test hole USW H-1. The altitude of the land surface at test hole USW UZ-1 is $1,348.48 \mathrm{~m}$ above sea level.

\section{DRILLING AND CASING METHODS}

The first large-diameter ( $444 \mathrm{~mm}$ ) test hole for which vacuum/reverse-aircirculation drilling was used to collect hydrologic data from the unsaturated zone in the Yucca Mountain area was test hole USW UZ-1. Drilling started on April 27, 1983, and the total depth of $387.1 \mathrm{~m}$ was reached on July 16, 1983. A vacuum/reverse-air-circulation drilling method (Houghton, 1969) was used. A dual-walled string of pipe, which had an inside diameter of $14 \mathrm{~cm}$ and an outside diameter of $22 \mathrm{~cm}$, was connected to a vacuum unit at the land surface that was used to remove cuttings from the borehole. From the inner string, the drill-bit cuttings were routed via the kelly hose to a dry separator for sample collection (fig. 2). (The diameter of the inner string of pipe needs to be large in order to minimize the head losses due to excessive friction that might occur during the drilling of deep boreholes.) The dry separator contained two chambers that could be separated by a hydraulic slide gate, which prevented vacuum loss in the system when drill-bit cuttings were being collected from the lower part of the dry separator. When closed, the slide gate enabled drilling to continue and the drill-bit cuttings to accumulate in the upper compartment of the dry separator as cuttings were collected from the lower compartment of the separator; thus, simultaneous drilling and sample collection could occur. After samples were collected for lithologic and hydrologic analyses, the remaining drill-bit cuttings were vibrated out of the lower chamber of the dry separator and removed from the collection area by a conveyor belt.

The dust particles that did not settle out in the dry separator were vacuumed into a wet separator where the dust was removed by a water spray, and the remaining clean air was exhausted to the atmosphere through the vacuum unit and exhaust muffler ( $f i g .2$ ). The water spray removed almost all of the dust before it passed through the vacuum unit and exhaust muffler to the atmosphere.

Advantages of using vacuum/reverse-air-circulation for drilling are: (1) Continuous, representative drill-bit cuttings can be obtained, which permits a moisture profile to be made of the unsaturated rocks that are drilled; (2) excessive drying is not a factor, because only a minimal quantity of air flows in the well boce; (3) contamination of drill-bit cuttings does not occur, because no drilling fluids are used; (4) most of the drill cuttings and small rock fragments are vacuumed from the borehole which reduces the potential for plugging of fractures and provides a cleaner borehole for air or water injection tests; (5) detection of perched-water or moist zones occurs as soon as the zone is penetrated; and (6) atmospheric contamination can be detected after completion of the test hole by sampling for tracer gas. 


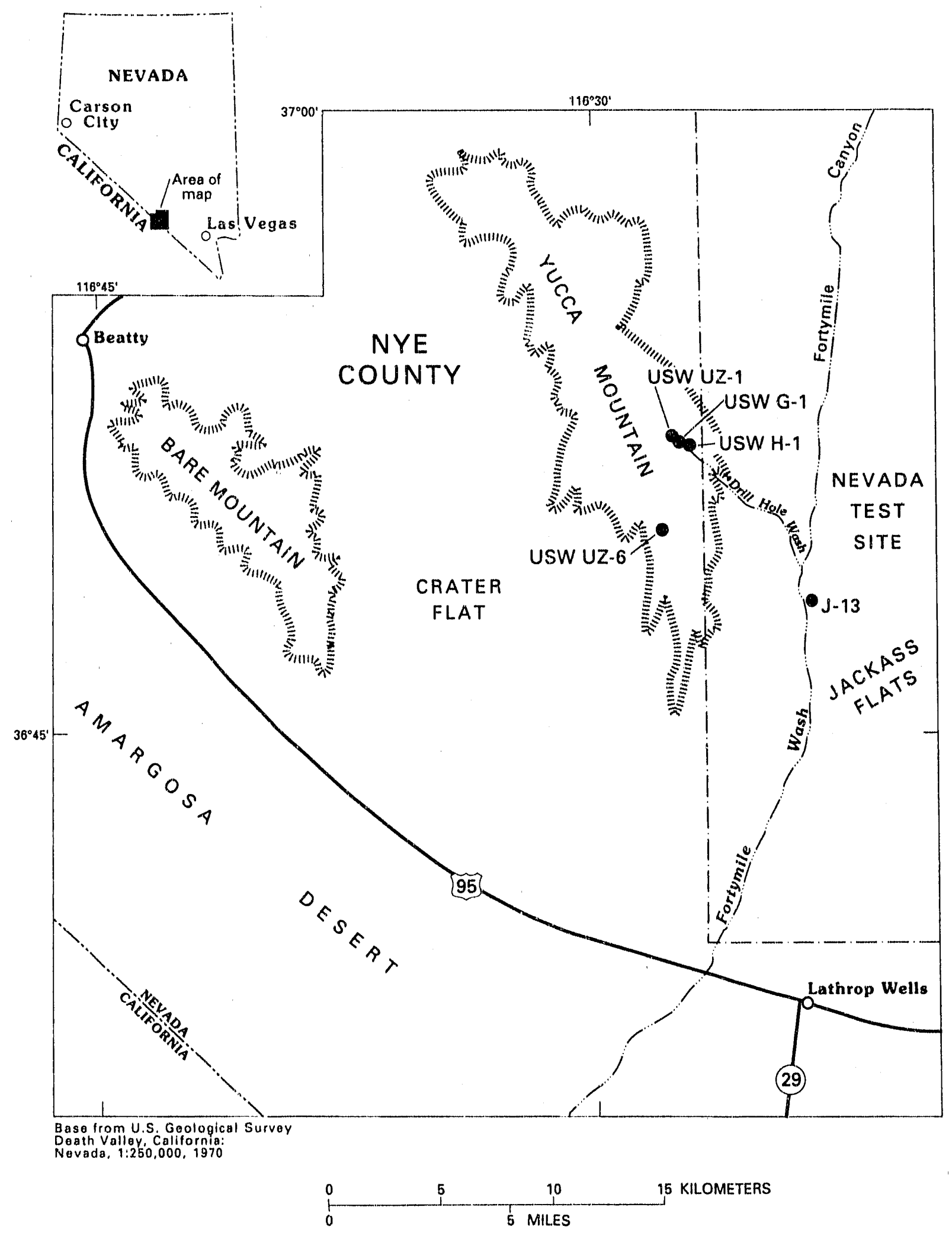

Figure 1.--Location of test hole USW UZ-1, nearby test holes, and geographic features. 


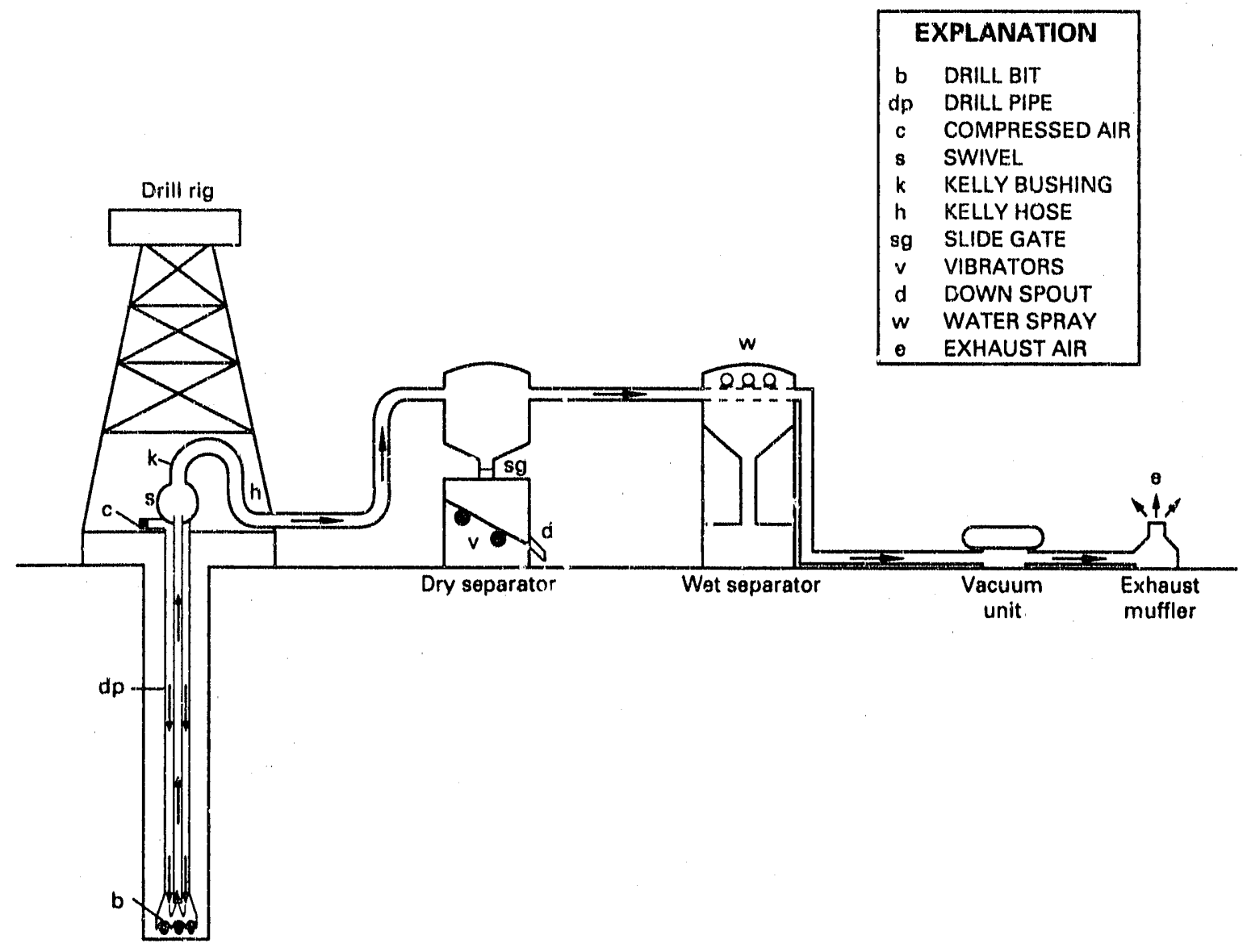

Figure 2.--Schematic diagram of separators, vacuum unit, and exhaust muffler.

One method to determine the presence or absence of atmospheric gas in the rocks adjacent to the borehole is by using a tracer gas, such as sulfur hexafluoride, injected into the borehole during drilling. Small quantities of this gas are piped to the intake manifold of an air compressor, which injects compressed air into the annulus between the inner pipe and the inside of the larger dual-wall pipe. Sulfur hexafluoride was added to the compresser air injected into this test hole at a concentration of 50 to $60 \mathrm{~cm}^{3} / \mathrm{min}$. The compressed air, in addition to adding a tracer gas, also helped cool the drill bit and assisted the vacuum system in the removal of drill cuttings from the bit. When necessary, the outer pipe also was used to inject small quantities of water to clean the bit. Therefore, any atmospheric gas that enters the borehole during the drilling process can be detected later. To make accurate age determinations of water contained in rocks, it is essential that rocks not be contaminated by ambient atmospheric gases, such as carbon dioxide. Prior to stemming and instrumenting the test hole, the test hole was vacuumed for several hours to remove consaminated atmospheric air. Subsequent gas samples from different depths, however, indicated that some atmospheric air coitamination still was present in the test hole. 
Disadvantages of using vacuum/reverse-air-circulation for drilling are that: (1) More extensive equipment and a larger drilling site are needed than for conventional drilling methods; (2) unstable hole conditions are produced by vacuuming, resulting in frequent caving and redrilling; (3) the method is unsuitable for collection of representative hydrologic cores; and (4) in most zones, plugging of the drill bit by mud encrustation of the inner string and kelly hose restricts movement of dril1-bit cuttings to the land surface.

When the rock-moisture content exceeds 5 percent by weight, plugging of the system occurs and drilling needs to be stopped, or the drill bit will be buried in drill cuttings, and will become stuck. Drilling can be resumed only after the bit, inner string, and kelly hose are cleaned and dried by blowing dry compressed air through them.

Initially, a 1,219-mm-diameter conductor hole was augered to a depth of $12.6 \mathrm{~m}$ at the site of test hole USW UZ-1, and a 1,067-mm-diameter conductor pipe was cemented to a depth of $12 \mathrm{~m}$. On June 1, 1983, drilling of a 914-mmdiameter borehole began, using vacuum/reverse-air drilling, in alluvium to a depth of $29.6 \mathrm{~m}$. Then, a $610-\mathrm{mm}$-diameter borehole was drilled from 29.6 to $30.8 \mathrm{~m}$, a 444-mm-diameter borehole was drilled from 30.8 to $385.6 \mathrm{~m}$, a $381-\mathrm{mm}-$ diameter borehole was drilled from 385.6 to $386.8 \mathrm{~mm}$, and a $235-\mathrm{mm}$ borehole was drilled from 386.8 to $387.1 \mathrm{~m}$, the total depth. Bit, casing, and cementing data are listed in table 1 . Drilling through the alluvium was difficult because it caved in around the drilling assembly. Because the caved-in material caused the bit to clog, water in quantities ranging from 0.076 to $0.13 \mathrm{~L} / \mathrm{s}$ was added with the air to clean and cool the bit. This small quantity of added water, however, made a muddy mixture that was difficult to remove from the hule. About $0.44 \mathrm{~L} / \mathrm{s}$ of water would have been needed to remove the cuttings using conventional drilling methods, but such methods were not used because too much water would have been added to the borehole. At a depth of $17 \mathrm{~m}$, the drill bit encountered hard rock. At a

Table 1.--Bit, casing, and cementing data

$[--$, no data $]$

\begin{tabular}{|c|c|c|c|c|c|c|c|c|}
\hline \multirow{2}{*}{\multicolumn{3}{|c|}{$\begin{array}{l}\text { Drilled } \\
\text { interval } \\
\text { (meters) }\end{array}$}} & \multirow{2}{*}{$\begin{array}{c}\text { Bit } \\
\text { diameter } \\
\text { (milli- } \\
\text { meters) }\end{array}$} & \multirow{2}{*}{$\begin{array}{l}\text { Cased } \\
\text { interval } \\
\text { (meters) }\end{array}$} & \multirow{2}{*}{$\begin{array}{l}\text { Casing inside } \\
\text { diameter } \\
\text { (millimeters) }\end{array}$} & \multicolumn{3}{|c|}{$\begin{array}{l}\text { Intervals cemented and } \\
\text { volume of cement used }\end{array}$} \\
\hline & & & & & & \multicolumn{2}{|c|}{$\begin{array}{l}\text { Depth } \\
\text { (meters) }\end{array}$} & $\begin{array}{c}\text { Volume } \\
\text { (cubic metrrs) }\end{array}$ \\
\hline 0 & to & 1.2 .6 & 1,219 & 0 to 12.0 & 1,041 & 0 & to 12.0 & 12.2 \\
\hline 12.6 & to & 29.6 & 914 & -- & -- & & -- & -- \\
\hline 29.6 & to & 30.8 & 610 & -- & -- & & -- & -- \\
\hline${ }^{1} 30.8$ & to & 385.6 & 444 & -- & -- & 372.2 & to 378.9 & 1.0 \\
\hline 130.8 & to & 385.6 & 444 & $-\infty$ & -- & 382.5 & to 385.6 & 0.4 \\
\hline${ }^{2} 385.6$ & to & 386.8 & 381 & -- & -- & 385.6 & to 386.5 & 0.1 \\
\hline$? 386.8$ & to & 387.1 & 235 & -- & -- & & $-m$ & -- \\
\hline
\end{tabular}

${ }^{1}$ Junk basket, 381 millimeters in diameter, and crossover sub left in hole from 378.9 to 382.5 meters.

${ }^{2}$ Fill in hole from 386.5 to 387.1 meters. 
depth of $17.5 \mathrm{~m}$, the penetration rate decreased due to an accumulation of water in the borehole that could not be vacuumed out. A diaphragm pump was installed in the borehole. About $1,514 \mathrm{~L}$ of water were removed in addition to $1,970 \mathrm{~L}$ of water that probably were removed with $2.5 \mathrm{~m}^{3}$ of fill that caved in from the sides of the borehole. This total approximates the 3,445 L of water added to the borehole during drilling. After removing the diaphragm pump, the borehole was dried by circulating air.

During drilling at a depth of 13 to $17 \mathrm{~m}$, small quantities of water from well $\mathrm{J}-13$ were added with the air to clean the pulverized rock from the drill bit. About $20 \mathrm{mg} / \mathrm{L}$ of lithium bromide was added to the water as a tracer. Water was stored and mixed with this tracer in a Baker tank. ${ }^{1}$

The drilling continued using compressed air and vacuum/reverse-air circulation without water. Dry drilling progressed slowly because it was necessary to pull the drill pipe and bit from the hole periodically either to remove pulverized rock material from the teeth of the bit or to clean out the vacuum hose between the swivel and dry separator. A 610-mm-diameter borehole was drilled from 29.6 to $30.8 \mathrm{~m}$. From depths of 30.8 to $385.6 \mathrm{~m}$, the borehole was drilled with a $444-\mathrm{mm}$-diameter bit. The combination of smaller borehole diameter and the use of a Gardner Denver vacuum pump enabled the volume of drill-bit cuttings to be removed as soon as they were cut, thus preventing them from being pulverized and clogging the bit. When the pulverized drillbit cuttings became wet from moisture condensation, the hoses became clogged, thus blocking the vacuum from the blower, and had to be cleaned.

Drilling continued without major problems until water was encountered at $383 \mathrm{~m}$ in the densely welded Topopah Spring Member. A water sample was collected, and chemical analysis of water indicated that it had a large concentration of polymer mud identical to that used during the coring of geologic test hole USW G-1, located about $0.3 \mathrm{~km}$ southeast of test hole USW UZ-1. The daily fluid losses from test hole USW G-1 averaged almost 77,600 L throughout the entire drilling period. Most of this loss was in a fractured zone that exists in the thick, densely welded zone of the Topopah Spring Member, and it is thought that the drilling fluid "lost" during the drilling of test hole USW G-1 formed a temporary, linear water zone that exterded along this fracture to test hole USW UZ-1.

Bailing attempts to dry the water-producing zone proved unsuccessful. The borehole was deepened to a total depth of $387.1 \mathrm{~m}$. Fill was left in the bottom of the borehole from 386.5 to $387.1 \mathrm{~m}$. The borehole was plugged with cement from 372.2 to $378.9 \mathrm{~m}$ and from 382.5 to $386.5 \mathrm{~m}$ in an effort to seal off the water inflow so dry drilling could be resumed. In an attempt to core through the cement plugs, the junk basket and a crossover sub became stuck in the cement from 378.9 to $382.5 \mathrm{~m}$, and the drilling operation was discontinued after the drill pipe was retrieved.

${ }^{1}$ The use of trade or firm names in this report is for identification purposes only and does not constitute endorsement by the U.S. Geological. Survey. 
One of our initial objectives was to drill through the entire unsaturated zone at this location. When water was encountered at a shallower depth than was expected and when it was determined by a chemical analysis that this water was contaminated with the polymer that was used during drilling of test hole USW G-1, the possible occurrences of the water encountered were (1) a contaminated perched water zone, (2) the contaminated natural water table, or (3) a zone of polymer drilling fluid. A future, deep, unsaturated-zone test hole, USW UZ-14, has been planned, which should help determine the natural unsaturated-saturated contact at this location.

The drilling rate and borehole deviation are shown in figure 3 . Borehole deviation was 1.5 degrees or less from the vertical. A detailed drilling history is contained in the files of the engineering contractor, Fenix \& Scisson of Nevada (formerly Fenix \& Scisson, Inc). Instrumenting, stemming, and grouting of this test hole was completed on October 24, 1983, so that fluid-flow potentials in the unsaturated zone could be monitored.

\section{CORING METHODS}

Most coring attempts were made using a Globe junk basket. One coring attempt, however, was made using a drive-core method, and another attempt was made using a rotary-coring method. The cored intervals are listed in tuble 2.

\section{Coring with the Junk Basket}

Coring using the Globe junk basket was complicated and had limited success. The junk basket was impeded by fill between the rock and the cutting edge, causing much friction and blockage of the core into the core barrel. only short cores, about $1 \mathrm{~m}$ long, could be collected, and recovered material generally was rubble. The rriction resulted in the production of heat that in turn resulted in moisture loss from the recovered core. Water-content and water-potential measurements made in core samples were not considered representative of the formation conditions. Total recovery of core was only 12 percent. The junk basket frequently became stuck in the fill at the bottom of the hole.

\section{Drive Core}

The drive-core method was used in an attempt to collect a core sample from the depth interval from 76.07 to $76.20 \mathrm{~m}$. Drive coring was attempted by repeatedly driving or dropping the drill string with a $0.91-\mathrm{m}-1$ long section of 273-mm-outside-diameter casing that had a beveled outside edge. No penetration could be made after driving the first $127 \mathrm{~mm}$. No core was recovered by using this method because the hard, poorly consolidated rock fell out of the drive casing.

\section{Rotary Core}

Rotary coring using a Kore-King core barrel and a 2.16-mm-diameter by 102 -mm-1ong core bit was attempted in the interval from 304.80 to $307.85 \mathrm{~m}$. However, most of the core fell out of the core catcher, and only $0.15 \mathrm{~m}$ of core was recovered, which represented only a 5-percent recovery. 


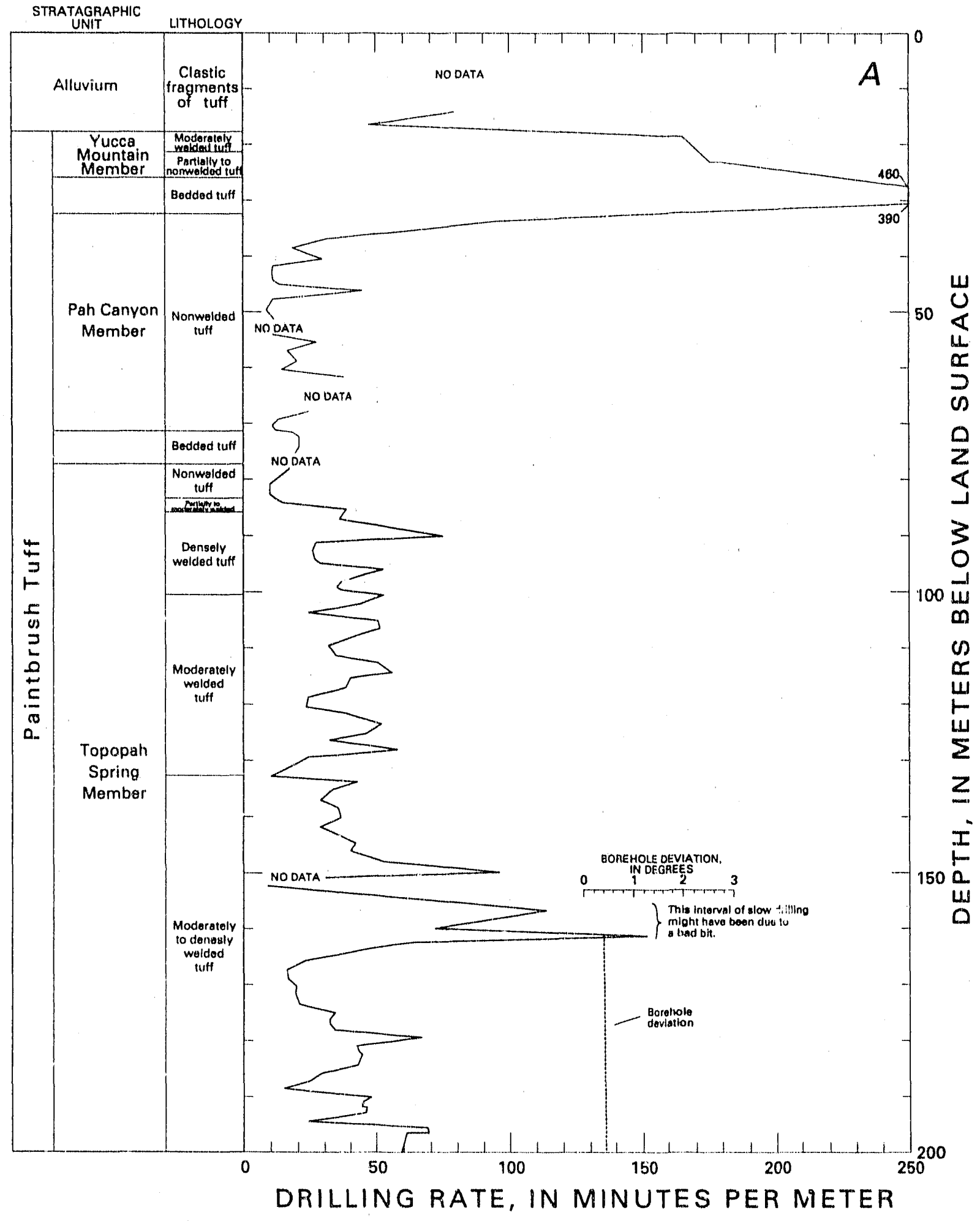

Figure 3.--Drilling rate and borehole deviation from depths of: $A, 0$ to 200.0 meters; and $B, 200.0$ to 382.5 meters. 


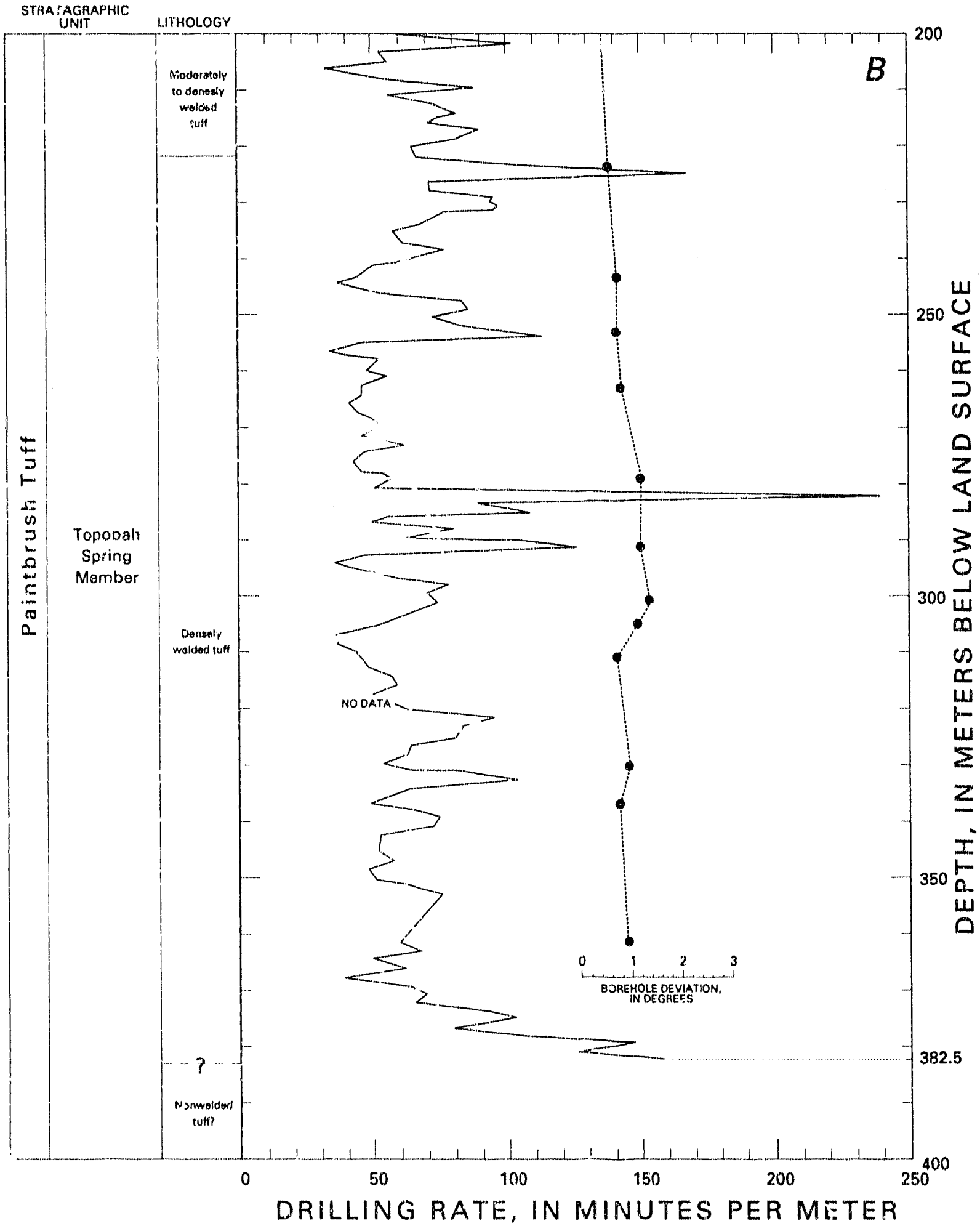

Figure 3.--Drilling rate and borehole deviation from depths of: $A$, ) to 200.0 meters; and $B, 200.0$ to 382.5 meters--Continued. 
Table 2.--Cored intervals (Globe junk basket)

\begin{tabular}{cccc}
\hline $\begin{array}{c}\text { Core } \\
\text { number }\end{array}$ & $\begin{array}{c}\text { Depth interval } \\
\text { (meters) }\end{array}$ & $\begin{array}{c}\text { Interval thickness } \\
\text { (meters) }\end{array}$ & $\begin{array}{c}\text { Core recovered } \\
\text { (meters) }\end{array}$ \\
\hline 1 & 16.76 to 17.22 & 0.5 & 0 \\
2 & 21.95 to 24.08 & 2.13 & .61 \\
3 & 29.57 to 30.78 & 1.21 & .61 \\
4 & 51.82 to 52.43 & .61 & .43 \\
5 & 52.43 to 53.04 & .61 & .61 \\
6 & 53.04 to 53.64 & .60 & .30 \\
7 & 176.07 to 76.20 & .13 & .53 \\
8 & 76.20 to 76.81 & .61 & .43 \\
9 & 106.68 to 107.11 & .43 & .15 \\
10 & 152.40 to 153.01 & .61 & .61 \\
11 & 2304.80 to 307.85 & 3.05 & 0 \\
12 & 383.44 to 384.20 & .76 & 0 \\
13 & 385.27 to 386.18 & .91 & 0 \\
14 & 386.18 to 386.48 & .30 & .91 \\
15 & 385.57 to 386.48 & 1.07 & 0 \\
16 & 386.03 to 387.10 & .07 & .15 \\
\hline
\end{tabular}

${ }^{1}$ Attempted to drive core by repeatedly driving or dropping the drill string with a 0.91 -meter-long section of 273-millimeter-outside-diameter casing.

${ }^{2}$ Drilled with conventional circulation using air and a core barrel that had a 216-mm-diarneter by 102-mm-long core bit.

\section{SAMPLE COLLECTION AND HANDLING}

Rock samples were collected for lithologic and hydrologic determinations. Samples consisted of drill-bit cuttings and cores.

\section{Drill-Bit Cuttings}

Samples of drill-bit cuttings were collected at about $0.6-\mathrm{m}$ intervals at depths from 20.7 to $29.9 \mathrm{~m}$ and at about $1.5-\mathrm{m}$ intervals at depths from 32 to $387.1 \mathrm{~m}$. Drill-bit cuttings also were collected during the coring attempts ard reaming. After a prescribed interval had been drilled, cuttings were vibrated out of the dry separator by mechanical vibrators onto a conveyor belt, and a representative sample of these cuttings was immediately collected and placed into a $0.95-\mathrm{L}$ glass sample jar and capped with an airtight lid for laboratory analysis of water content and matric properties. A sample of coarse, sieved drill-bit cuttings also was collected for hydrologic laboratory determinations from each interval from a depth of $36.6 \mathrm{~m}$ to the total depth. Drill-bit cuttings from the conveyor belt were sieved rapidly through a 1.6 -mm mesh screen, and the coarse fragments were collected and placed in a second $0.95 \mathrm{~m}$ glass jar and capped with an airtight lid. Sample cuttings that were first released from the bottom of the dry separator were not collected because 
of longer residence time in the separator and because of the possibility of contamination from the cuttings left in the separator from the previous interval. An effort also was made to obtain a representative sample of the interval drilled by collecting portions of the total sample from different locations on the conveyor belt. More importantly, hydrologic sample collection and sieving were done quickly to minimize evaporation of vater from the cuttings.

After sample collection was completed, the samples were taken inmediately to a laboratory trailer on the drill site. At that time, a subsample from each container for each type of cutting was removed for water-content measurements. The lids of the glass sample jars then were sealed with vinyl tape for additional protection against evaporation, and the jars were stored until water-potential measurements could be made. In some instances, as many as 36 hours elapsed befcre water-content measurements could be made because of a backlog of samples.

\section{$\underline{\text { Core }}$}

Core from the Globe junk basket was placed into $0.3-m$-diameter-polyviny $1-$ chloride (PVC) pipe containers that had PVC caps affixed immediately after the shoe of the junk basket was removed. The heat produced by coring welded tuff without drilling fluids was too great to obtain valid water-related measurements. Core in the lower part of the junk basket generally was virtually dry and extremely hot from heat produced by the cutting bit. Core in the upper part of the junk basket usually was moist; in some instances, water collected on the top of the core. Apparently, interstitial water from the lower part of the core evaporated and condensed on the cooler metal of the upper part of the junk basket.

\section{GEOPHYSICAL LOGS}

Geophysical logs of test hole USW UZ-1 were made by the Birdwell Division of the Seismograph Service Corp., a subsidiary of Raytheon Co. The main objectives were to: (1) Determine exact depths of major stratigraphic units and lithologic changes; (2) obtain porosity and fracture data; and (3) gage the diameter of the open hole to determine volume of stemming material needed around the hydrologii instruments. The types of logs and the depth intervals logged are listed in table 3 .

Caliper logs were obtained to determine a vertical profile of borehole diameter. A vertical distribution of the depths where out-of-gage intervals of the borehole occurred is listed in table 4; the percentage of out-of-gage borehole for each stratigraphic unit penetrated is summarized in table 5 . Out-of-gage is defined in this report as a diameter that is $100 \mathrm{~mm}$ greater than the diameter of the bit used to drill the borehole. Some of the enlarged zones identified by the caliper $\log$ are associated with rock fracturing. 
Table 3.--Geophysical logs obtained in the borehole

\begin{tabular}{lrr}
\hline \multicolumn{1}{c}{$\begin{array}{c}\text { Types of } \\
\text { geophysical log }\end{array}$} & Ruri number & $\begin{array}{r}\text { Depth interval } \\
\text { (meters) }\end{array}$ \\
\hline Caliper & 1 & 380 to 383 \\
Caliper & 2 & 3 to 383 \\
Casing-collar locator & 1 & 299 to 380 \\
Casing-collar locator & 2 & 351 to 369 \\
Casing-collar locator & 3 & 358 to 360 \\
Casing-collar locator & 4 & 305 to 345 \\
Density & 1 & 6 to 29 \\
Density, borehole compensated & 1 & 27 to 384 \\
water locator & 1 & 351 to 371 \\
Water locator & 2 & 351 to 360 \\
Water locator & to & 3 to 371 \\
Fluid density for water location & $1-\mathrm{A}$ & 357 to 382 \\
Fluid density for water location & $1-B$ & 357 to 382 \\
Fluid density for water location & 2 & 335 to 379 \\
Fluid density for water location & 3 & 375 to 385 \\
Fluid density for water locatior & 4 & 357 to 369 \\
Fluid density for water location & 5 & 357 to 369 \\
Gamma ray & 1 & 3 to 380 \\
Gamma ray & 2 & 3 to 25 \\
Spectralog gamma ray (5-inch) & 1 & 0 to 383 \\
Spectralog gamma ray (2-inch) & 1 & 0 to 383 \\
Epithermal neutron porosity & 1 & 24 to 385 \\
Epithermal neutron porosity & 2 & 3 to 30 \\
Induction & 1 & 3 to 383 \\
Dielectric log (5-inch) & 1 & 12 to 383 \\
\hline
\end{tabular}


Table 4.--out-of-gage borehole intervals

\begin{tabular}{|c|c|c|c|c|}
\hline \multirow{2}{*}{ Stratigraphic unit } & \multicolumn{3}{|c|}{$\begin{array}{l}\text { Depth interval } \\
\text { (meters) }\end{array}$} & \multirow{2}{*}{$\begin{array}{c}\begin{array}{c}\text { Interval thickness } \\
\text { (meters) }\end{array} \\
\begin{array}{c}1.46 \\
.64\end{array}\end{array}$} \\
\hline & $\begin{array}{r}{ }^{1} 12.04 \\
16.76\end{array}$ & $\begin{array}{l}\text { to } \\
\text { to }\end{array}$ & $\begin{array}{l}13.50 \\
17.40\end{array}$ & \\
\hline Yucca Mountain Member & $\begin{array}{l}17.40 \\
18.04 \\
18.53 \\
19.29 \\
20.60 \\
21.92 \\
23.16\end{array}$ & $\begin{array}{l}\text { to } \\
\text { to } \\
\text { to } \\
\text { to } \\
\text { to } \\
\text { to } \\
\text { to }\end{array}$ & $\begin{array}{l}17.68 \\
18.35 \\
18.90 \\
20.12 \\
21.37 \\
22.71 \\
25.60\end{array}$ & $\begin{array}{r}.28 \\
.31 \\
.37 \\
.83 \\
.77 \\
.79 \\
2.44\end{array}$ \\
\hline Bedded tuff & $\begin{array}{l}25.60 \\
29.57 \\
30.78\end{array}$ & $\begin{array}{l}\text { to } \\
\text { to } \\
\text { to }\end{array}$ & $\begin{array}{l}28.53 \\
29.87 \\
32.00\end{array}$ & $\begin{array}{r}2.93 \\
.30 \\
1.22\end{array}$ \\
\hline Pah Canyon Member & $\begin{array}{l}32.00 \\
40.39 \\
42.98\end{array}$ & $\begin{array}{l}\text { to } \\
\text { to } \\
\text { to }\end{array}$ & $\begin{array}{l}39.01 \\
41.45 \\
44.20\end{array}$ & $\begin{array}{l}7.01 \\
1.06 \\
1.22\end{array}$ \\
\hline Bedded turf & 71.93 & to & 77.70 & 5.77 \\
\hline Topopah Spring Member & $\begin{array}{r}77.70 \\
150.11 \\
170.05 \\
260.15 \\
261.12 \\
262.71 \\
264.14\end{array}$ & $\begin{array}{l}\text { to } \\
\text { to } \\
\text { to } \\
\text { to } \\
\text { to } \\
\text { to } \\
\text { to }\end{array}$ & $\begin{array}{r}79.71 \\
150.54 \\
170.14 \\
260.30 \\
261.31 \\
263.96 \\
264.81\end{array}$ & $\begin{array}{r}2.01 \\
.43 \\
.09 \\
.15 \\
.19 \\
1.25 \\
.67\end{array}$ \\
\hline
\end{tabular}

${ }^{1}$ Weil cased to 12.04 meters. 
Table 5.--Percentage of out-uf-gage borehole for stratigraphic units penetrated

\begin{tabular}{lcl}
\hline \multicolumn{1}{c}{ Stratigraphic unit } & $\begin{array}{c}\text { Percentage of unit } \\
\text { out-of-gage }\end{array}$ & $\begin{array}{l}\text { Distribution within } \\
\text { stratigraphic unit }\end{array}$ \\
\hline Alluvium & 39 & Top and bottom of \\
uncased interval
\end{tabular}

Four television videotapes of borehole conditions were made, three in July 1983 and one in September 1983. The distribution of observed fractures is listed in table 6; a Rcse diagram of strikes of fractures is shown in figure 4. Measurements were made using a compass attached below the camera. No water seeps in the borehole were observed by the television camera or on the videotapes.

Table 6.--Fracture distribution observed using a downhole television camera

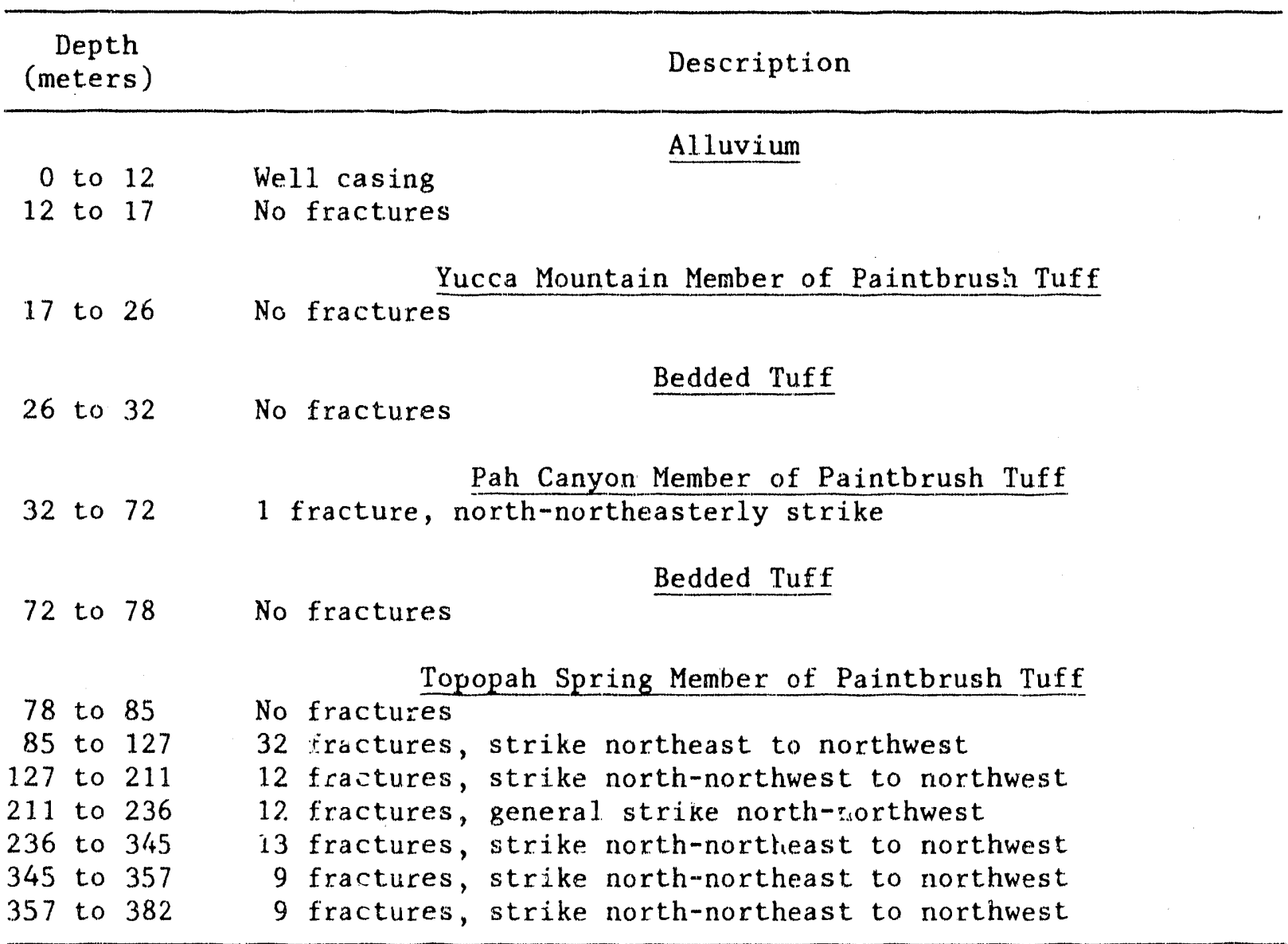




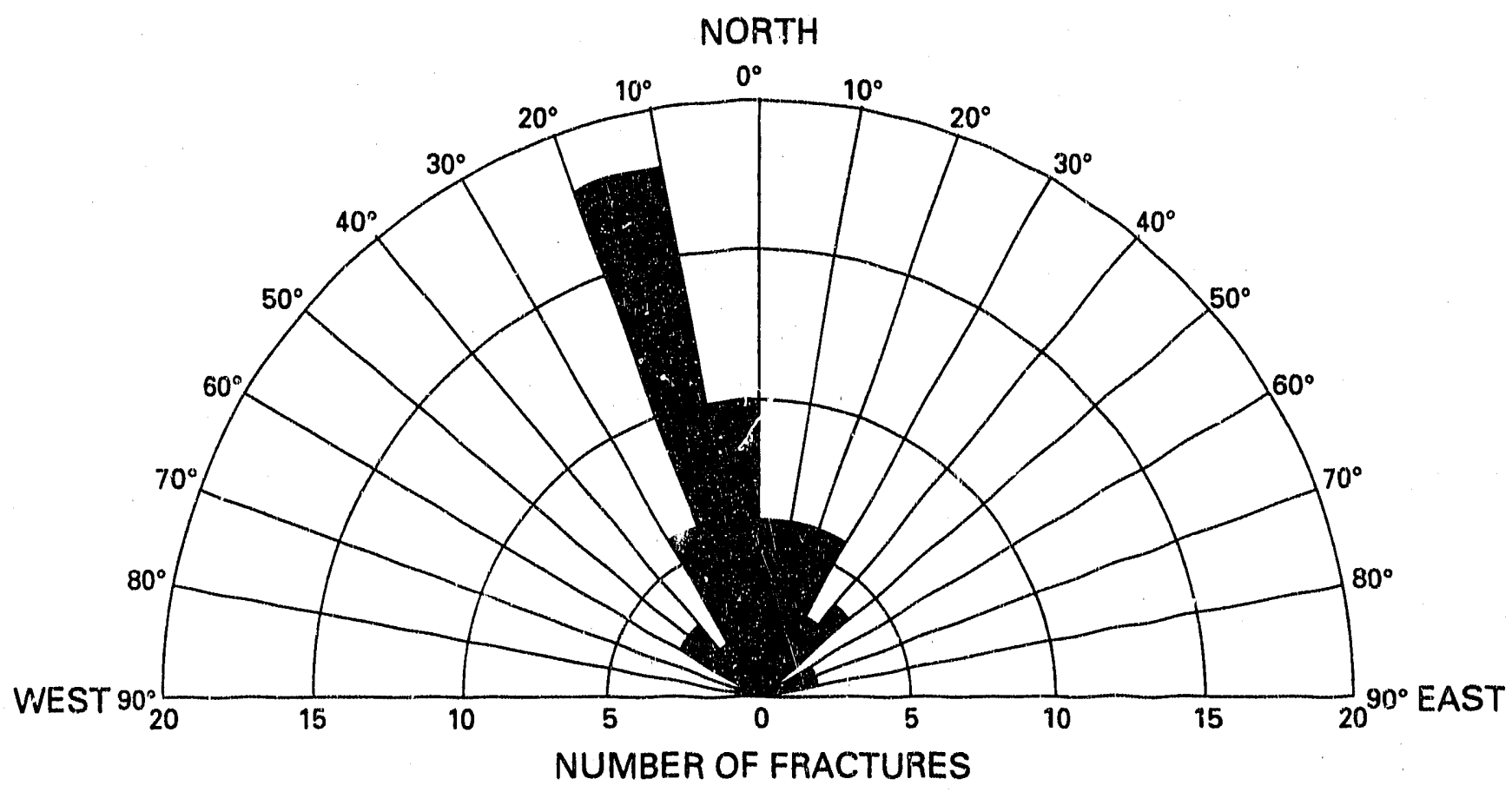

Figure 4.--Strikes of fractures.

\section{LITHOLOGY}

A lithologic log of rocks of Quaternary and Tertiary age penetrated during the drilling of test hole USW UZ-1 was made from drill-bit cuttings and cores and is listed in table 7. Contacts between the geologic units were cross-checked with geophysical logs, and the depths were corrected accordingly. Ash-flow tuff was the dominant rock type penetrated. The thick ash-flow-tuff beds are separated by bedded-tuff units that are each $6 \mathrm{~m}$ thick. The tuffs have various degrees of welding and induration as described in table 7 . Black glass shards were recovered during bailing when the borehole was $383.29 \mathrm{~m}$ deep indicating that the friable, nonwelded tuff at the base of the Topopah Spring Member was penetrated. Drill-rate-penetration curves (figs. $3 A$ and $3 B$ ) support the varying hardness of the tuffs caused by degree of welding and induration. 
Table 7.--Lithologic log of drill-bit cuttings

[Log compiled by Richard W. Spengler, U.S. Geological Survey, subject to revision]

\begin{tabular}{lll}
\hline & Thickness & Depth to \\
Stratigraphic and lithologic description & $\begin{array}{l}\text { of } \\
\text { (meterval }\end{array}$ & $\begin{array}{l}\text { interval } \\
\text { (meters) }\end{array}$ \\
\hline
\end{tabular}

A1. Iuvium

Clastic fragments of nonwelded to densely welded tuff, to 12.8 meters; monolithologic from 12.8 to 17.4 meters, consisting almost entirely of densely welded tuff of the Tiva Canyon Member; some caliche coated

Paintbrush Tuff

Yucca Mountain Member

Tuff, ash flow, pale brown, moderately welded, devitrified; extremely rare phenocrysts

Tuff, ash flow, dark yellowish-brown, partially welded to nonwelded, vitric, pumice commonly grayish-orange-pink, argillic (?); abundant black glass shards in matrix

Tuff, ash fall, light gray to white and pinkish-gray; predominantly composed of subrounded vitric pumice clasts, some of which are slightly altered to clays (?); poorly consolidated to unconsolidated

Pah Canyon Member

Tuff, ash flow, light brown, nonwelded, (poorly consolidated), vitric; punice, light olive-gray, vitric, relatively large; 5-percent phenocrysts of sanidine, plagioclase, biotite, and hornblende; sparse, pale reddish-brown, lithic volcanic fragments 
Table 7.--Lithologic log of drill-bit cuttings--Continued

\begin{tabular}{lll} 
Stratigraphic and lithologic description & $\begin{array}{c}\text { Thickness } \\
\text { of } \\
\text { interval } \\
\text { (meters) }\end{array}$ & $\begin{array}{l}\text { Depth to } \\
\text { bottom of } \\
\text { interval } \\
\text { (meters) }\end{array}$ \\
\hline
\end{tabular}

Paintbrush Tuff--Continued

Tuff, ash flow, medium brown, nonwelded, (poorly consolidated), vitric; pumice, commonly dusky yellow, vitric, large; 7to 8-percent phenocrysts of quartz, sanidine, plagioclase, biotite, hornblende; rare blackish-gray, lithic volcanic fragments

12.2

54.9

Tuff, ash flow, dark yellowish-brown, nonwelded (poorly consolidated), vitric [slightly argillic (?)]; pumice, commonly dark yellowish-brown to very pale orange, vitric; 10-percent phenocrysts of sanidine, biotite, hornblende; abundant black minute glass shards; sparse grayishred, lithic volcanic fragments

Bedded Tuff

Tuff, ash fall, reworked, light gray to very light gray, and dark yellowish-brown, vitric; poorly consolidated; poorly sorted

6.1 77.7

Topopah Spring Member

Tuff, ash flow, medium orange-pink to medium reddish-brown, nonwelded, vitric; pumice, medium orange-pink to medium reddish-brown, vitric; 2- to 3-percent phenocrysts of sanidine, biotite (black)

Tuff, ash flow, yellowish-gray, nonwelded, vitric; pumice, yellowish-gray, vitric; 2- to 3-percent phenocrysts of sanidine and biotite
4.6
83.8 
Table 7.--Lithologic log of drill-bit cuttings--Continued

\begin{tabular}{lll}
\hline Stratigraphic and lithologic description & $\begin{array}{l}\text { Thickness } \\
\text { of } \\
\text { interval } \\
\text { (meters) }\end{array}$ & $\begin{array}{l}\text { Depth to } \\
\text { bottom of } \\
\text { interval } \\
\text { (meters) }\end{array}$ \\
\hline
\end{tabular}

Paintbrush Tuff--Continued

Topopah Spring Member--Continued

Tuff, ash flow, brownish-gray and medium gray, partially to moderately welded (appears fused), vitric; pumice, light brownish-gray and brownish-gray, vitric; 1 - to 2-percent phenocrysts of sanidine, biotite; rare, dark-gray, lithic volcanic fragments

86.3

Tuff, ash flow, grayish-red, densely welded, glassy (vitrophyre); 15-percent phenocrysts, duminantly sanidine

1.2

Tuff, ash flow, grayish-brown to dusky brown, densely welded devitrified (caprock); some pumice displaying vapor-phase crystallization; 10percent phenocrysts of sanidine, bronze biotite, hornblende

13.1

100.6

Tuff, ash flow, pale brown, moderately welded, devitrified; pumice, pale red, dominately vapor-phase crystallization; 5- to 7-percent phenocrysts of sanidine, biotite

Tuff, ash flow, pale brown and light gray (mottled), moderately to densely welded, devitrified [upper lithophysal (?) zone]; pumice, light gray and pale brown, devitrified; 2- to 3-percent of phenocrysts, dominantly sanidine

Tuff, ash flow, medium brown and medium light gray (slightly mottled), densely welded, devitrified; less than 1-percent phenocrysts of sanidine 
Table 7.--Iithologic log of drill-bit cuttings--Continued

\begin{tabular}{lll}
\hline Stratigraphic and lithologic description & $\begin{array}{c}\text { Thickness } \\
\text { of } \\
\text { interval } \\
\text { (meters) }\end{array}$ & $\begin{array}{l}\text { Depth to } \\
\text { bottom of } \\
\text { interval } \\
\text { (meters) }\end{array}$ \\
\hline Paintbrush Tuff--Continued & & \\
Topopah Spring Member--Con'-inued & \\
$\begin{array}{l}\text { Tuff, ash flow, grayish-brown and light } \\
\text { brown (mottled), densely welded, } \\
\text { devitrified (might contain sparse } \\
\text { lithophysale); less than 1-percent } \\
\text { phenocysts of sanidine }\end{array}$ & 135.6 & $\mathbf{1} 370.3$ \\
\hline
\end{tabular}
depth.

${ }^{1}$ Samples were not available below a depth of 370 meters to the total

\section{SAMPLE-TESTING PROCEDURES AND RESULTS}

Several hydrologic properties were determined in the laboratory from the drill-bit cuttings. These properties included measurements of water content and water potential. Laboratory measurements of moisture content and matric p-operties from the larger drill-bit-cutting fragments were considered to be representative of in-situ conditions.

\section{Water-Content Measurements}

Water-content measurements by weight were obtained by using standard gravimetric, oven-drying methods (Gardner, 1965). Weight measurements were recorded to $0.01 \mathrm{~g}$, and samples were oven-dried for 18 hours at $105{ }^{\circ} \mathrm{C}$ in a forced-air drying oven. Sample size was as large as the moisture cans would permit, usually from 100 to $400 \mathrm{~g}$. Measurements were not replicated. The data from these measurements are presented in table 8 and are shown in figure 5. The fractions listed in table 8 consist of sieved (coarse) and unsieved samples that were collected directly from the conveyor belt. 


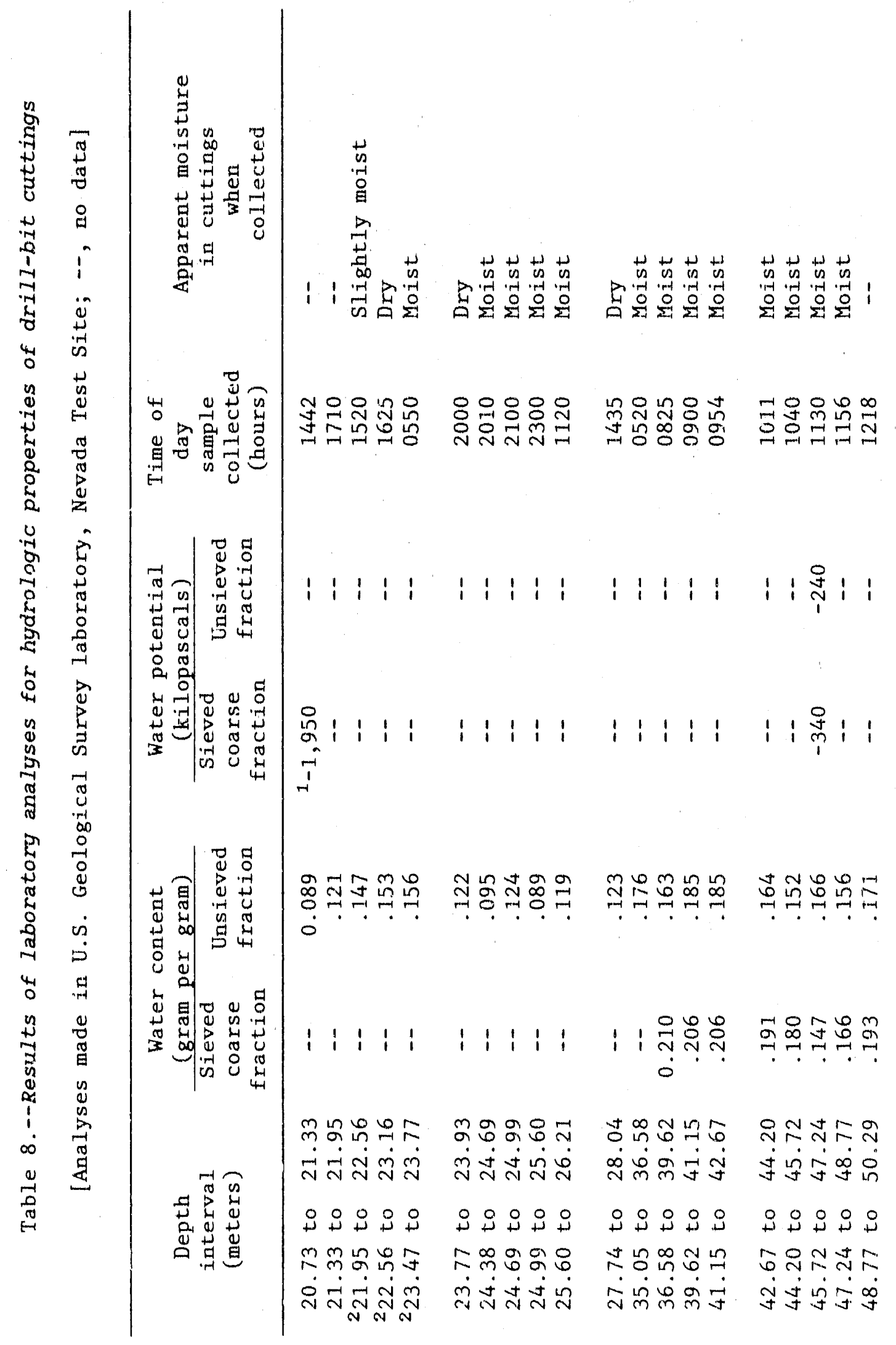




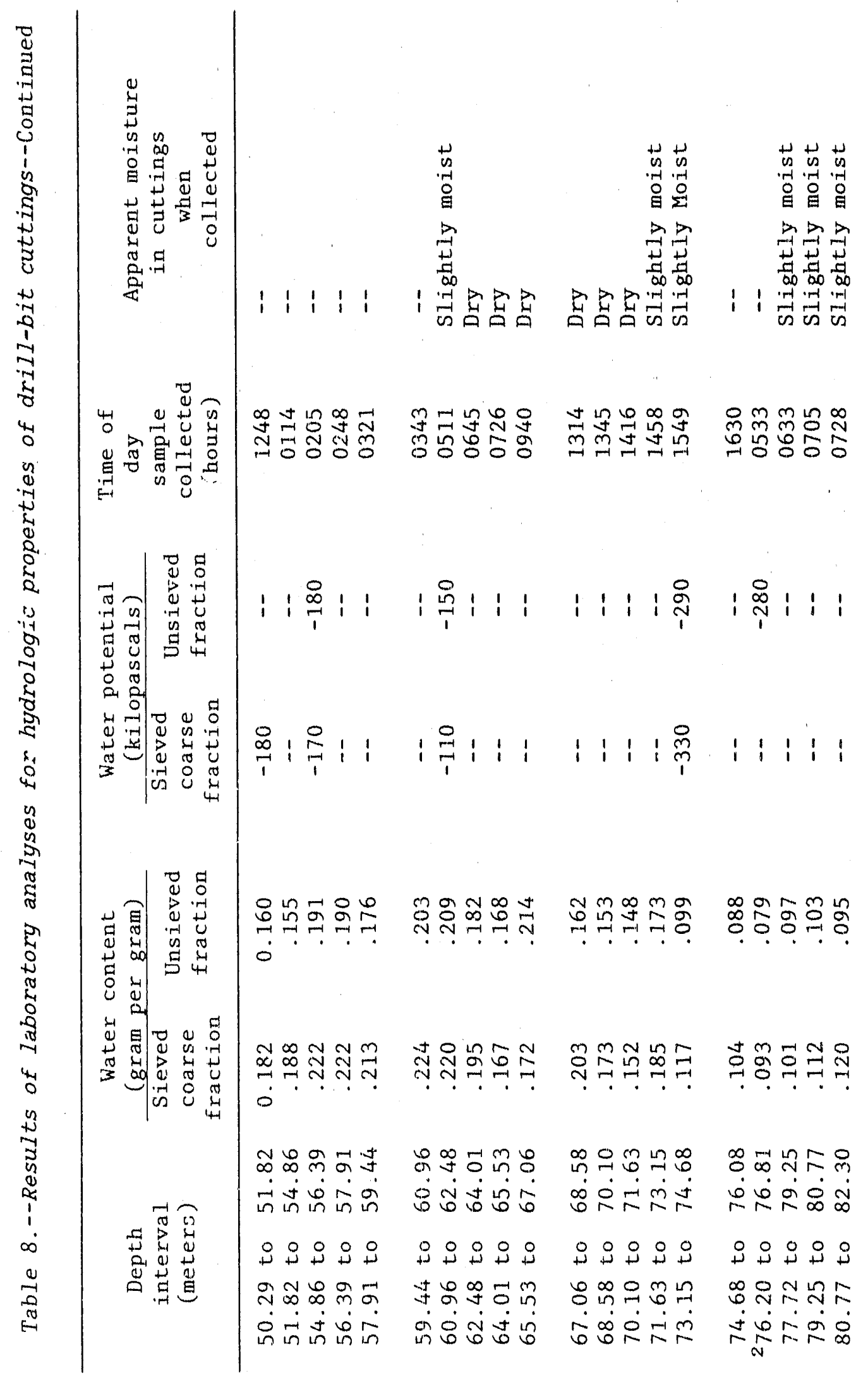




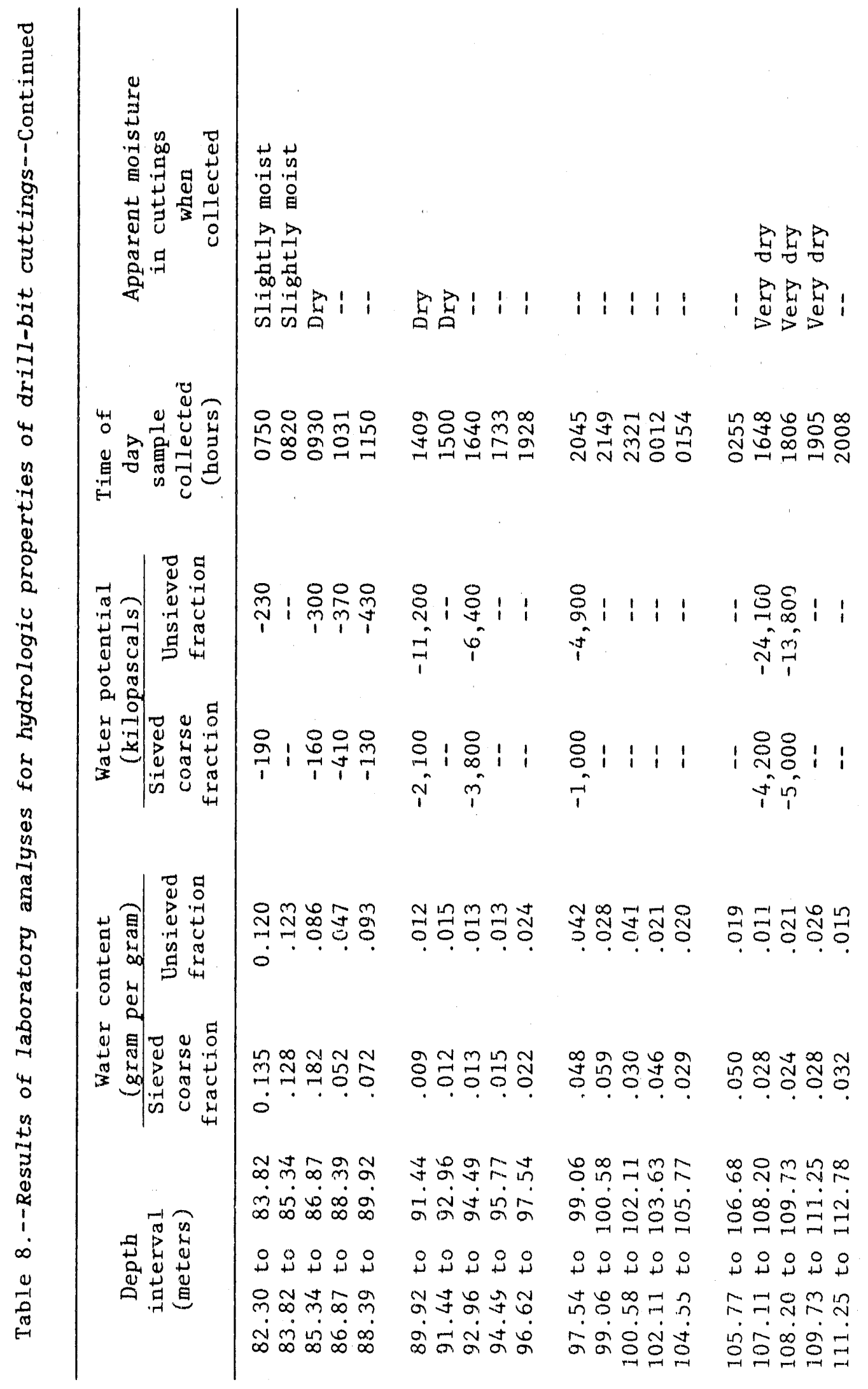




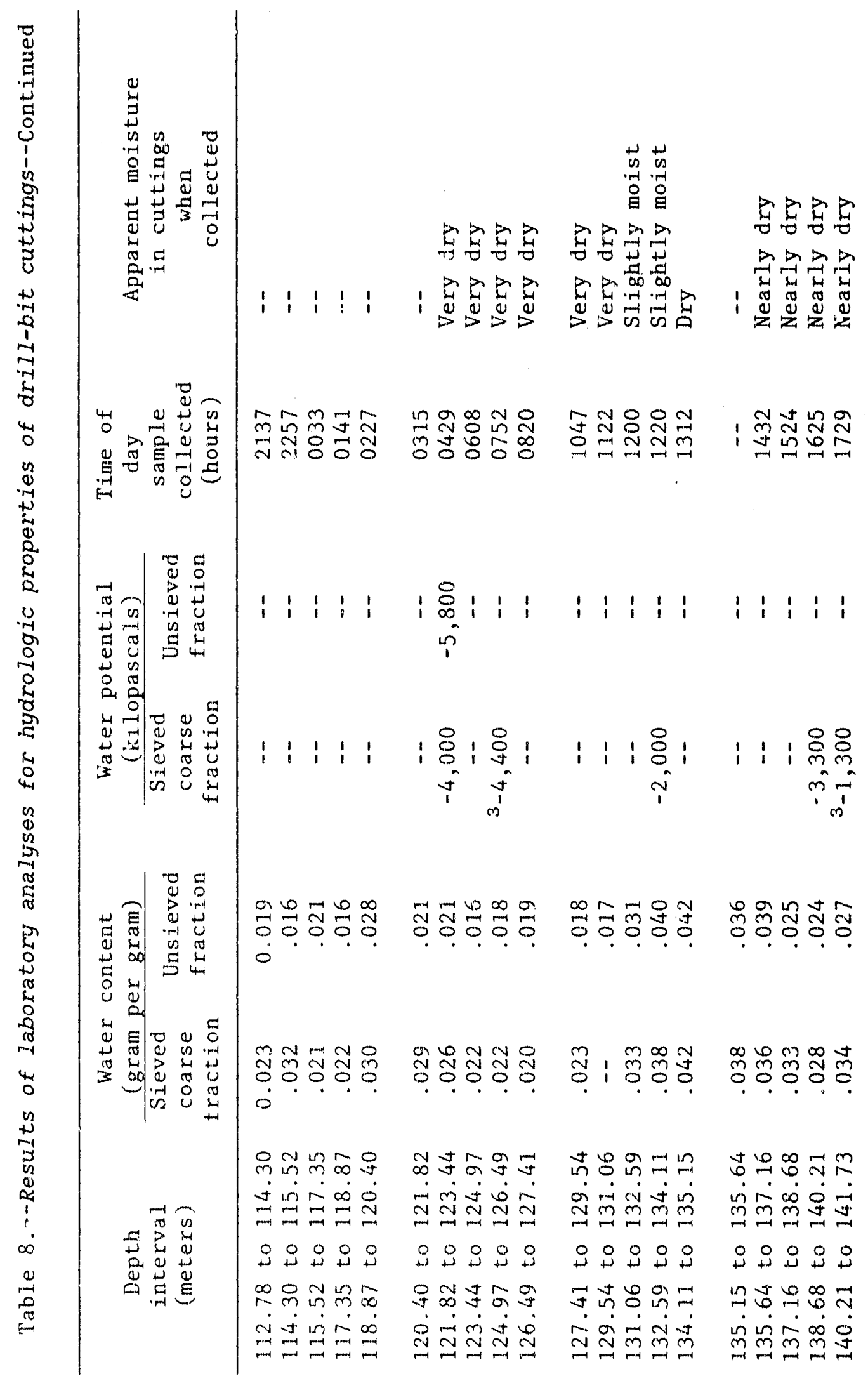




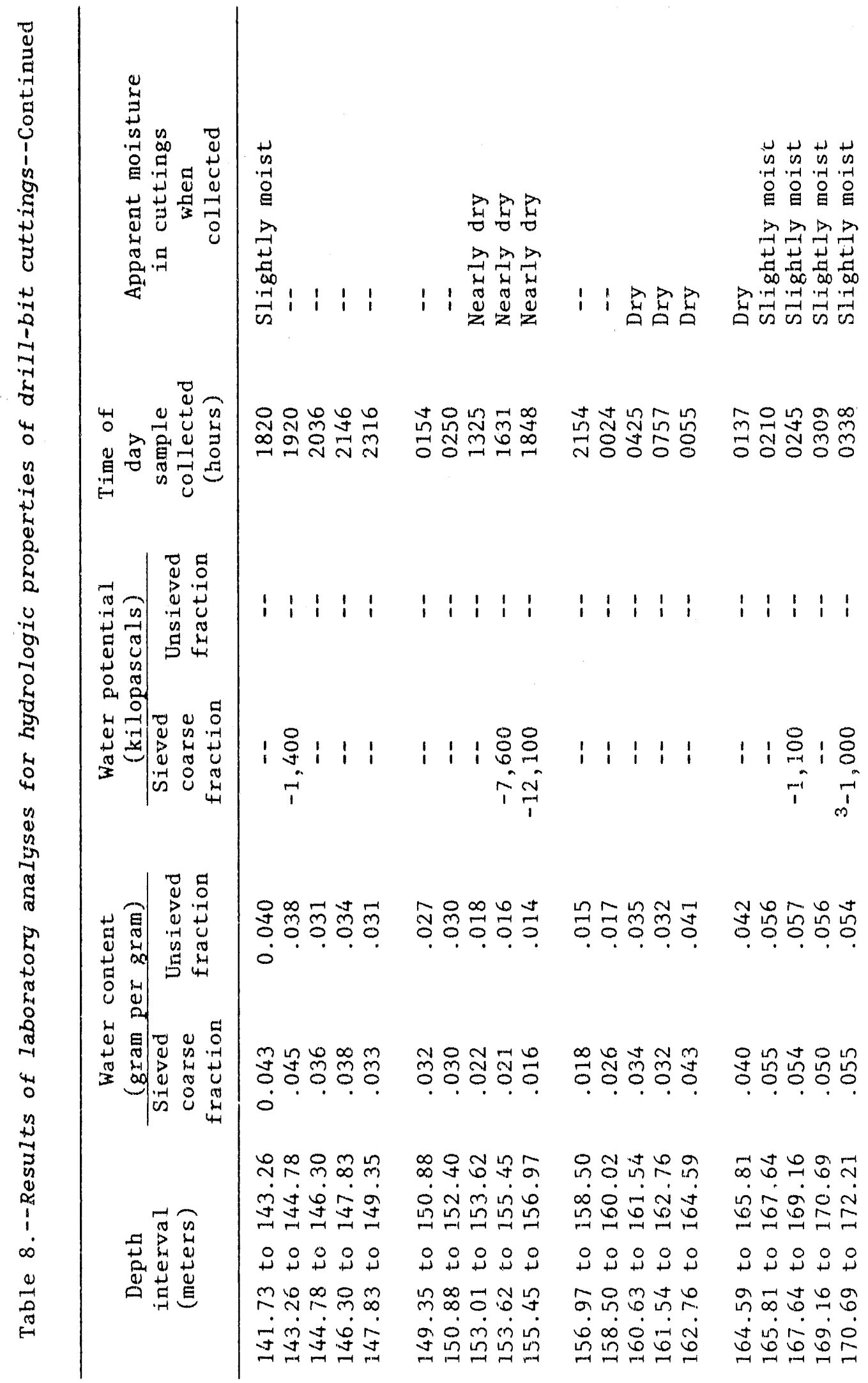




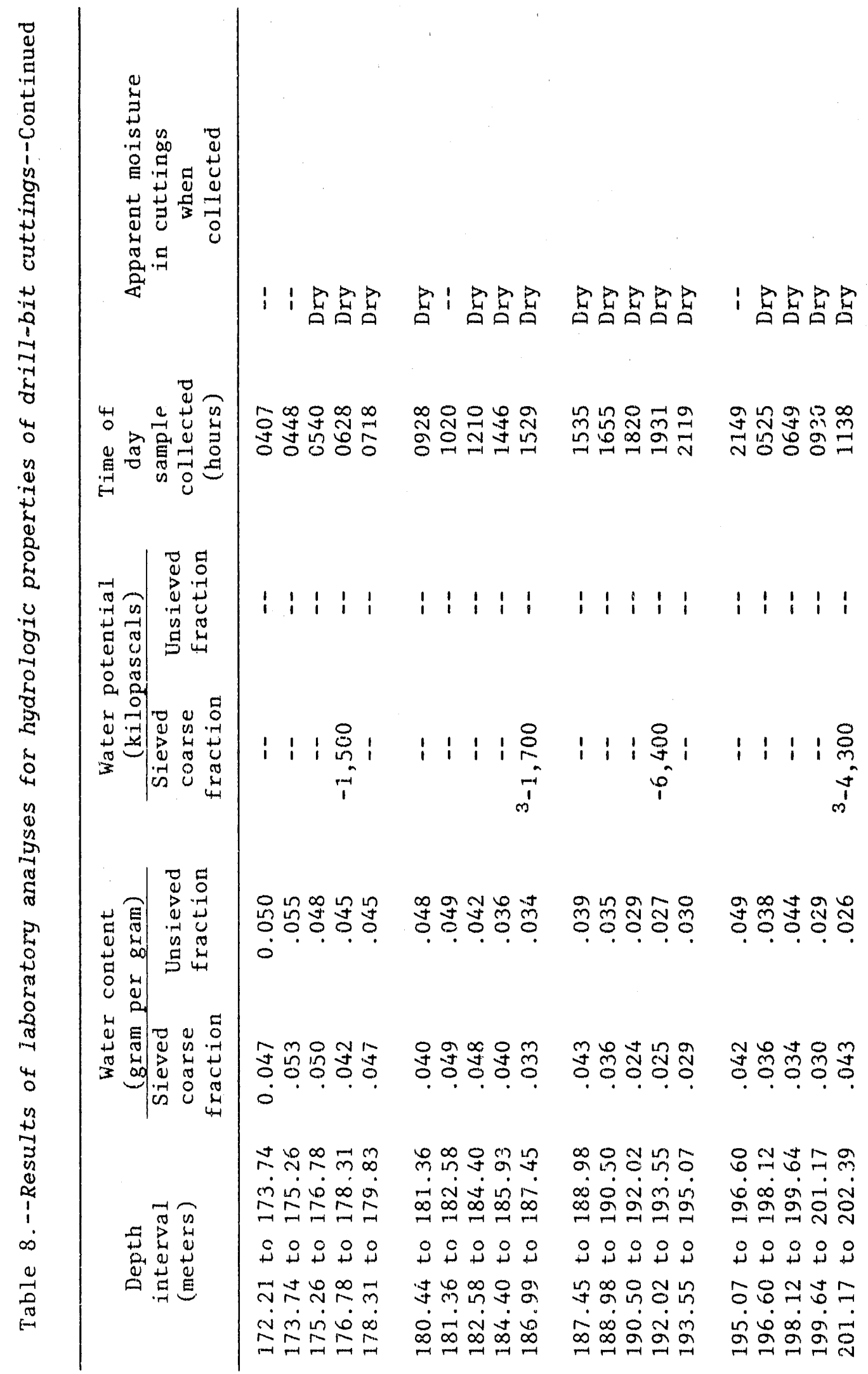




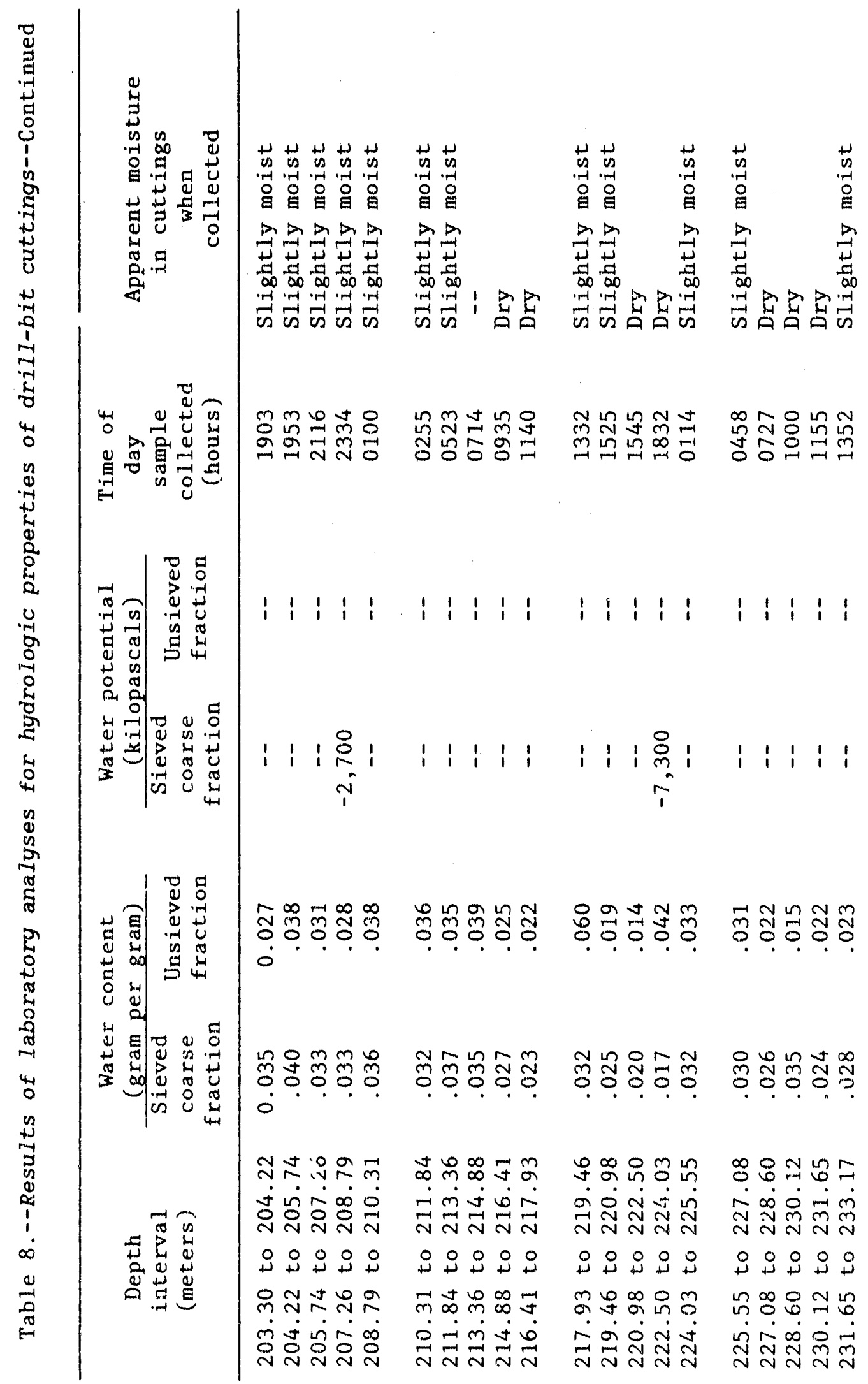




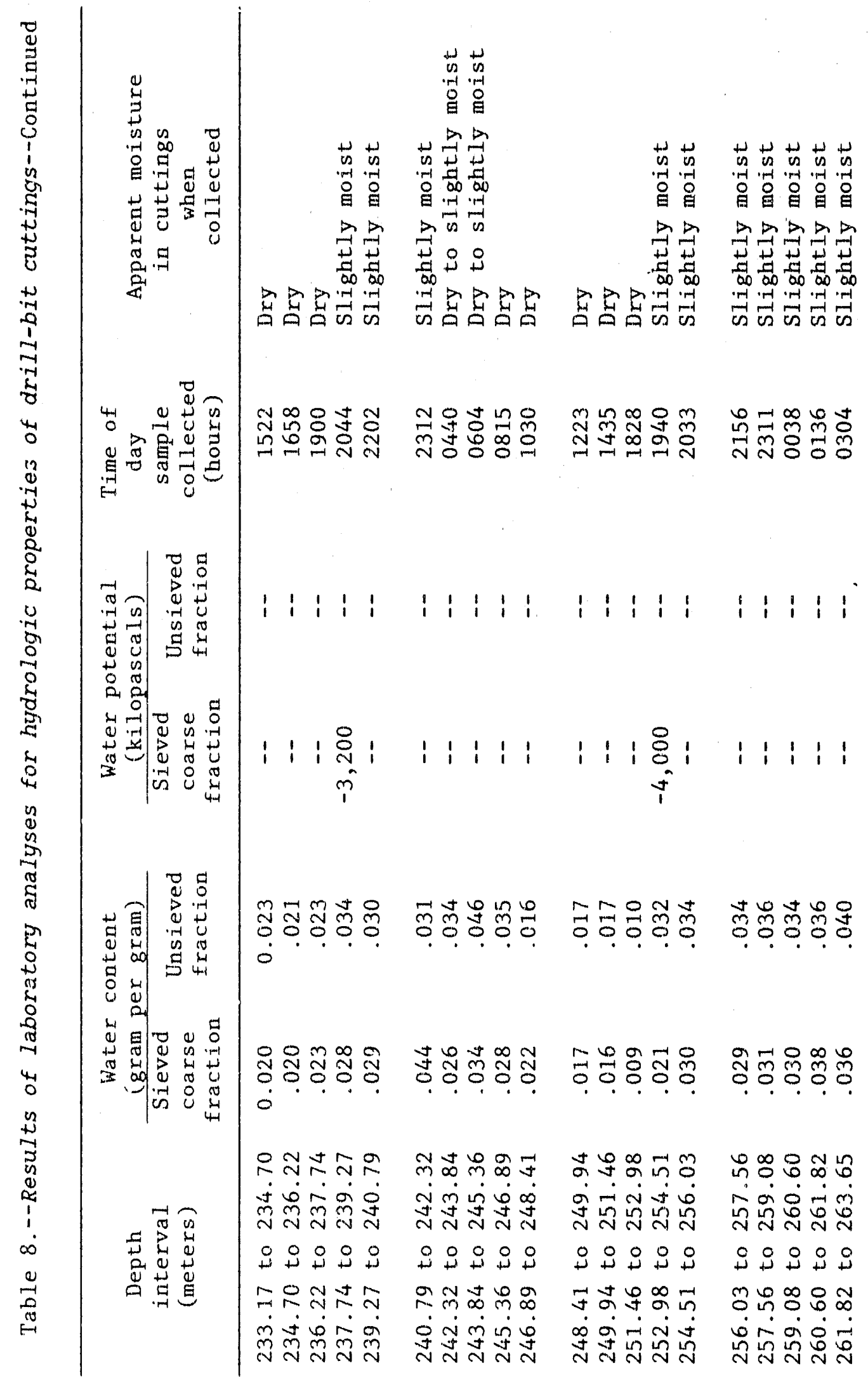




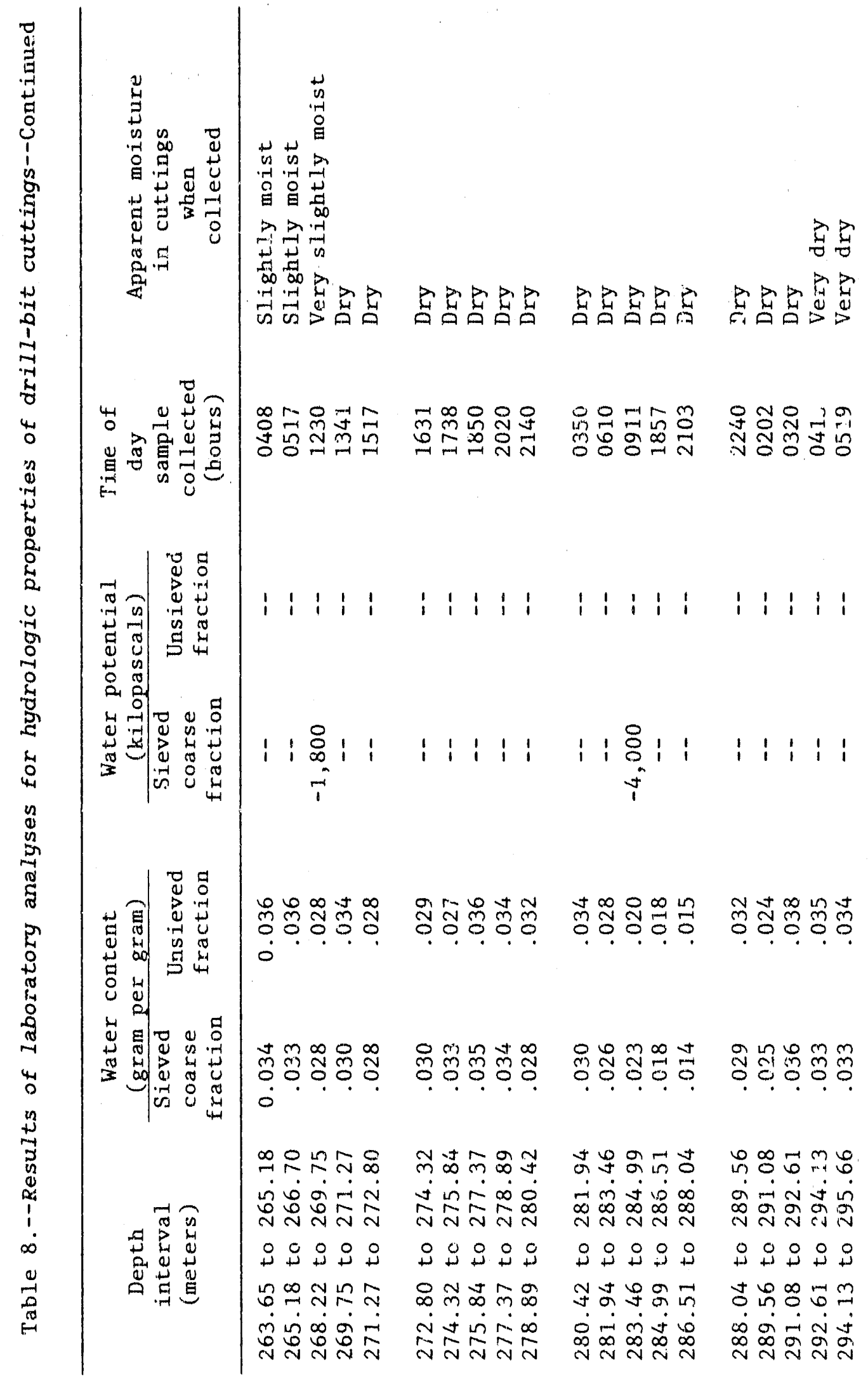




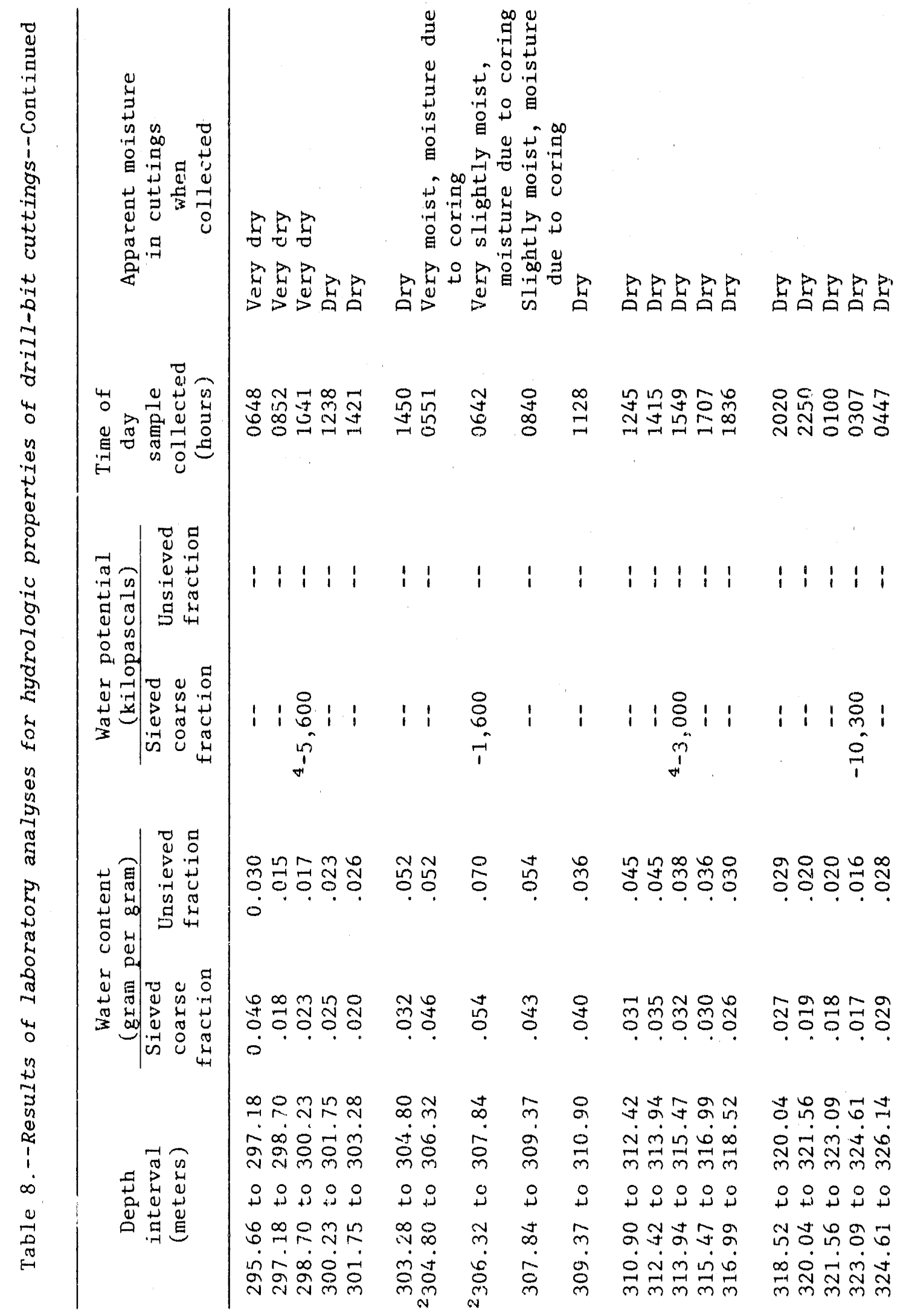




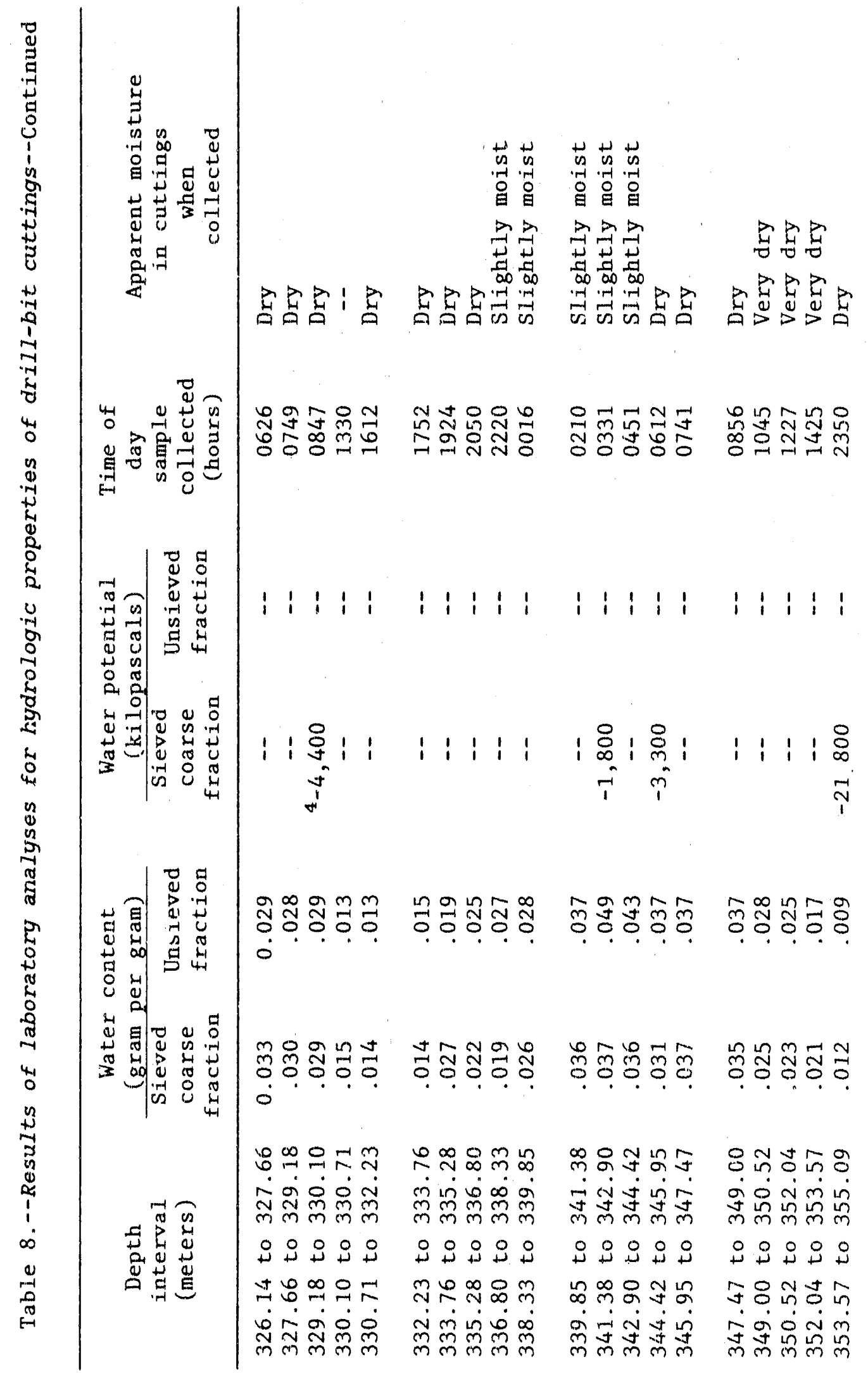




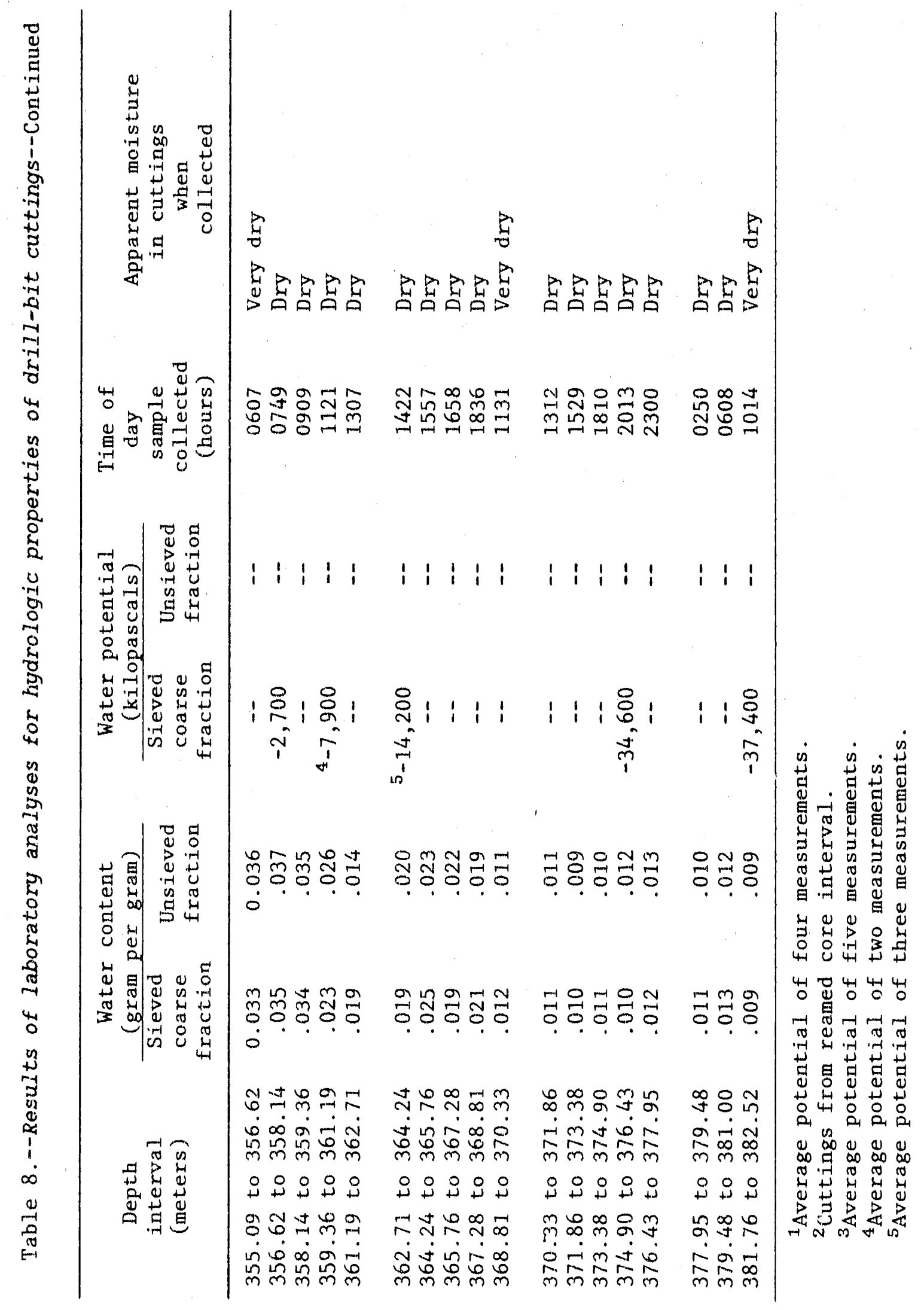




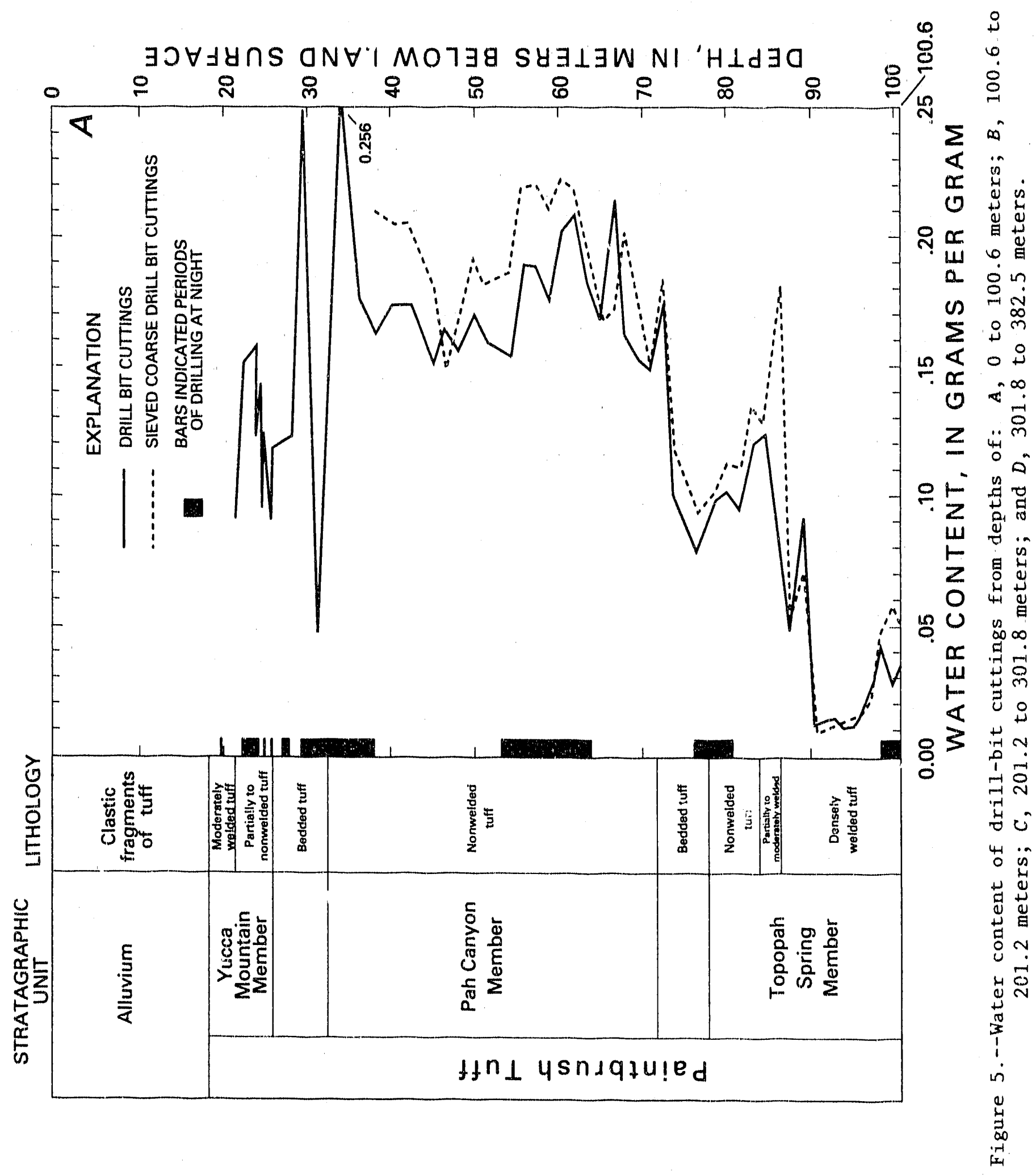




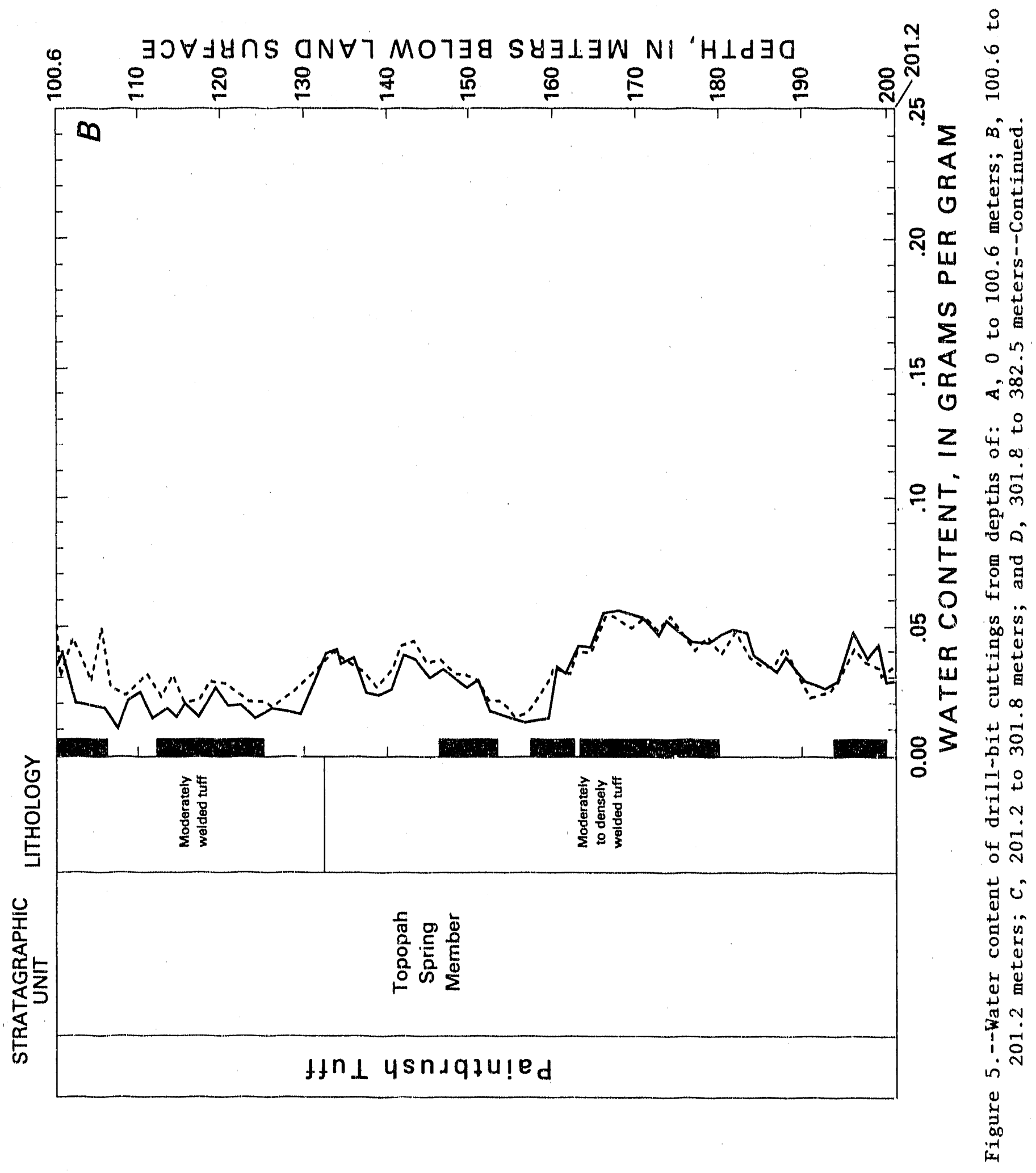




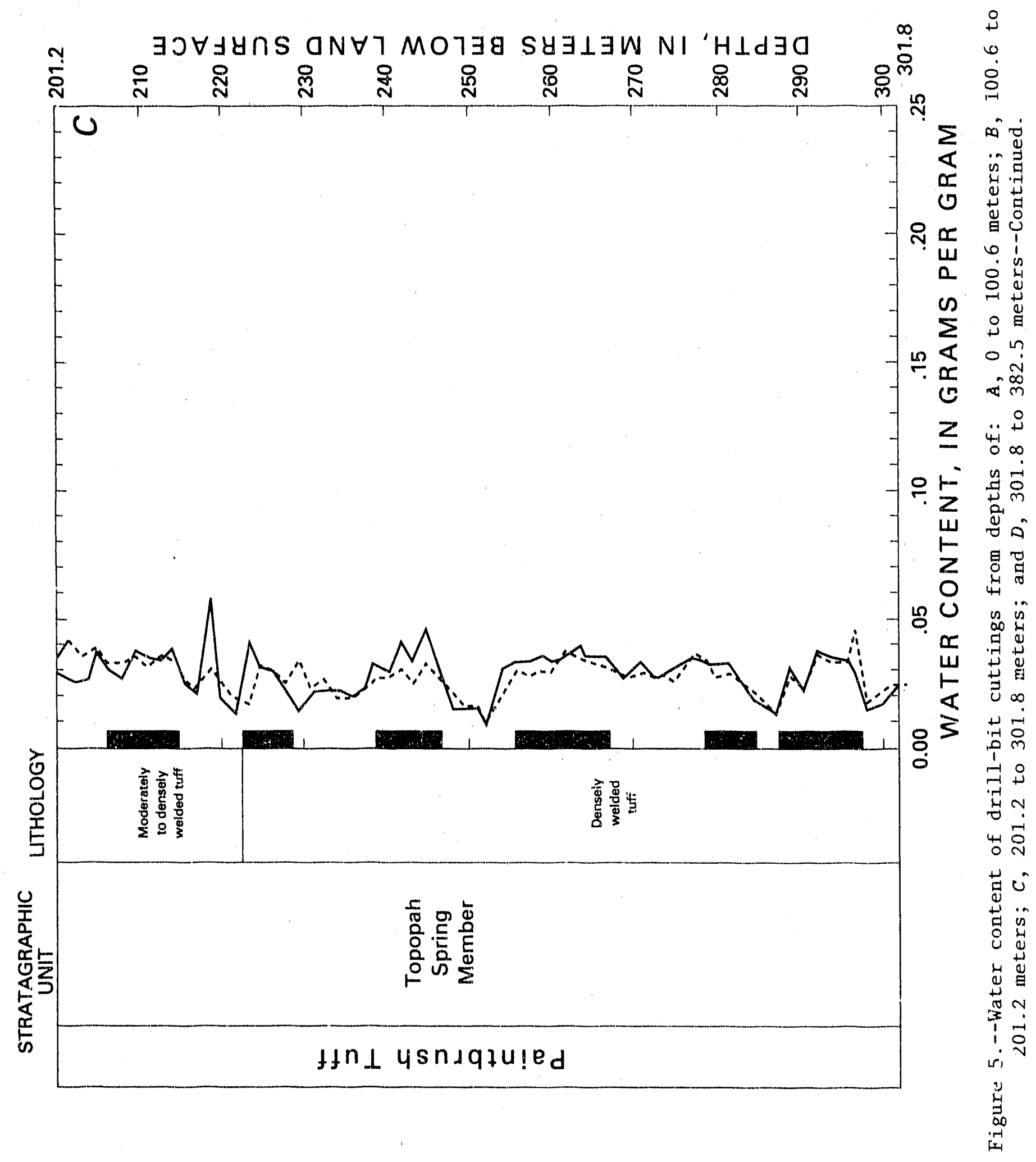




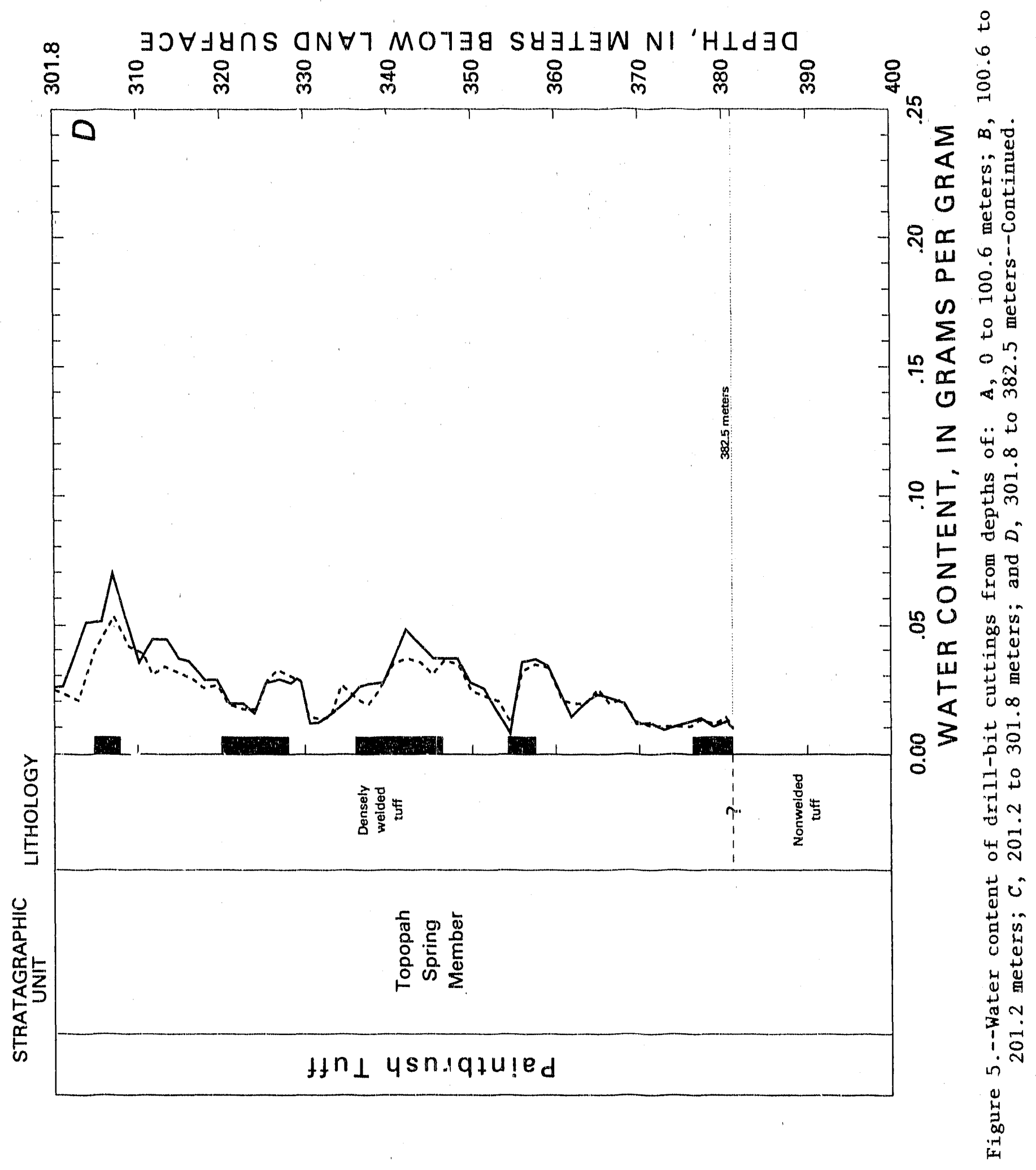


Water-Potential Measurements

Water potential is defined here as the sum of matric and osmotic potentials. Water potential was measured in this study using a $\mathrm{SC}-10$ thermocouple psychrometer from Decagon Devices, Pullman, Washington, and a Kiethly model 181 nanovoltmeter. The SC-10 consists of a stationary thermocouple psychrometer and 10 sample chambers that can be rotated to the thermocouple psychrometer. The Richards method (Richards and Ogata, 1958) was used in the measurements described herein to condense water on the thermocouple junction. In these measurements, calibration solutions were measured concurrently with actual rock samples to compensate for the zero drift of the nanovoltmeter amplifier. Generally, four of the chambers contained calibration solutions equivalent to known water potentials; five of the chambers contained samples; and the remajning chamber contained distilled water. Thermocouple output voltage was first measured on the known calibration standards, followed by measurements of output voltage from rock samples, and followed by output measurements of at least two of the calibration standards. If thermocouple output voltages differed because of zero drift between these replicate measurements of calibration standards by more than $0.1 \mu \mathrm{V}$, all calibration solutions were measured a second time, and the average was used for the construction of calibration curves. Calibration curves of water potential plotted against output voltage were nearly linear throughout the range of water potentials measured from -50 to $-7,000 \mathrm{kPa}$. Regression coefficients ranged from 0.986 to 1.000 ; most coefficients were equal to 1.000 .

The SC-10 sample chamber was rilled with calibration solutions and rock samples in a humidified glove box to minimize evaporation. After filling was completed, at least one-half hour was allowed to elapse before measurements were made so temperature and vapor equilibrium was achieved. To avoid temperature fluctuations, all measurements were made inside the glove box and generally at night when the air-conditioning system in the onsite laboratory trailer was able to keep the temperature relatively constant. All equipment, including the thermocouple junction, was meticulously cleaned after each set of measurements to prevent carry-over of salts or dust to the next set of measurements. Data from the water-potential measurements are presented in table 8 .

\section{HYDROLOGIC TESTING AND WATER SAMPLING}

Hydrologic testing was completed before a labo atory analysis indicated that this water contained a polymer identical to the one used in the drilling of nearby geologic test hole USW G-1, located about $0.3 \mathrm{~km}$ to the southeast. Water levels were measured, bailing was done, and a chemical analysis of the water sample collected was made. 
Water-Level Measuremen.s

Water levels were measured periodically in test hole USW UZ-1. Waiexlevel measurements are listed in table 9.

\section{Bailing}

Bailing of the test hole was done on July 14 and 15,1983 , in the uncased depth interval from 383 to $386 \mathrm{~m}$. During a 495 -minute period, $491.0 \mathrm{~L}$ of water were removed by bailing; the bailing rate was $0.0165 \mathrm{~L} / \mathrm{s}$.

\section{Physical and Chemical Analyses of Water}

On JuJ $\because 6,1983$, water was encountered during the drilling of test hole USW UZ-1 when the borehole had reached a depth of $383 \mathrm{~m}$; the depth of water below the land surface was $381.8 \mathrm{~m}$. The borehole was cleared of cuttings and bailed as dry as possible on July 11, 1983, allowed to recover for 4 hours, and sampled using a bailer. The sample contained large quantities of lightbrown suspended sediment. Measurements of specific conductance, $\mathrm{pH}$, and temperature, and bromide concentration were made onsite. Samples for inorganic-constituent determinations were centrifuged for several minutes prior to $0.45-\mu \mathrm{m}$ filtration to remove excess sediment. Rdw samples for organic "constituent determinations were collected in glass bott.les with foil-lined caps. Analytical results for the water sample from test hole USW UZ- 1 are 1 isted in table 10 .

A total-organic-carbon analysis and a methylene-chloride extraction, concentration, and gas chromatographic analysis using a flame-ionization detector were made. Standards were polymer number 4, liquid; Chevron DuraLith grease, EP-2 number 3, Jet-Lube; and Z-50, metallic zinc-base tool-joint compound, pipe dope. Several peaks from the chromotogram of the water sample matched with similar peaks of the polymer number 4 standard. These apparent light hydrocarbons, as confirmed by mass spectroscopy, probably are due to the 28 percent light hydrocarbons present in the polymex number 4, also called NALCO Adamite WFR-2. The later eluting peaks and rise in baseline seemed to natch the Jet-Lube number 1 standard. These peaks did not match as well as the polymer hydrocarbon peaks; however, the jet lube seemed to be the major contaminant in the samples. The grease and the pipe dope might have been present; however, even a large concentration did not present sufficient data. The analytical data seem to verify a connection between the water sample and the polymer and possibly the jet lube. Larger than normal concentrations of the standards were necessary to obtain chromatographic data. 

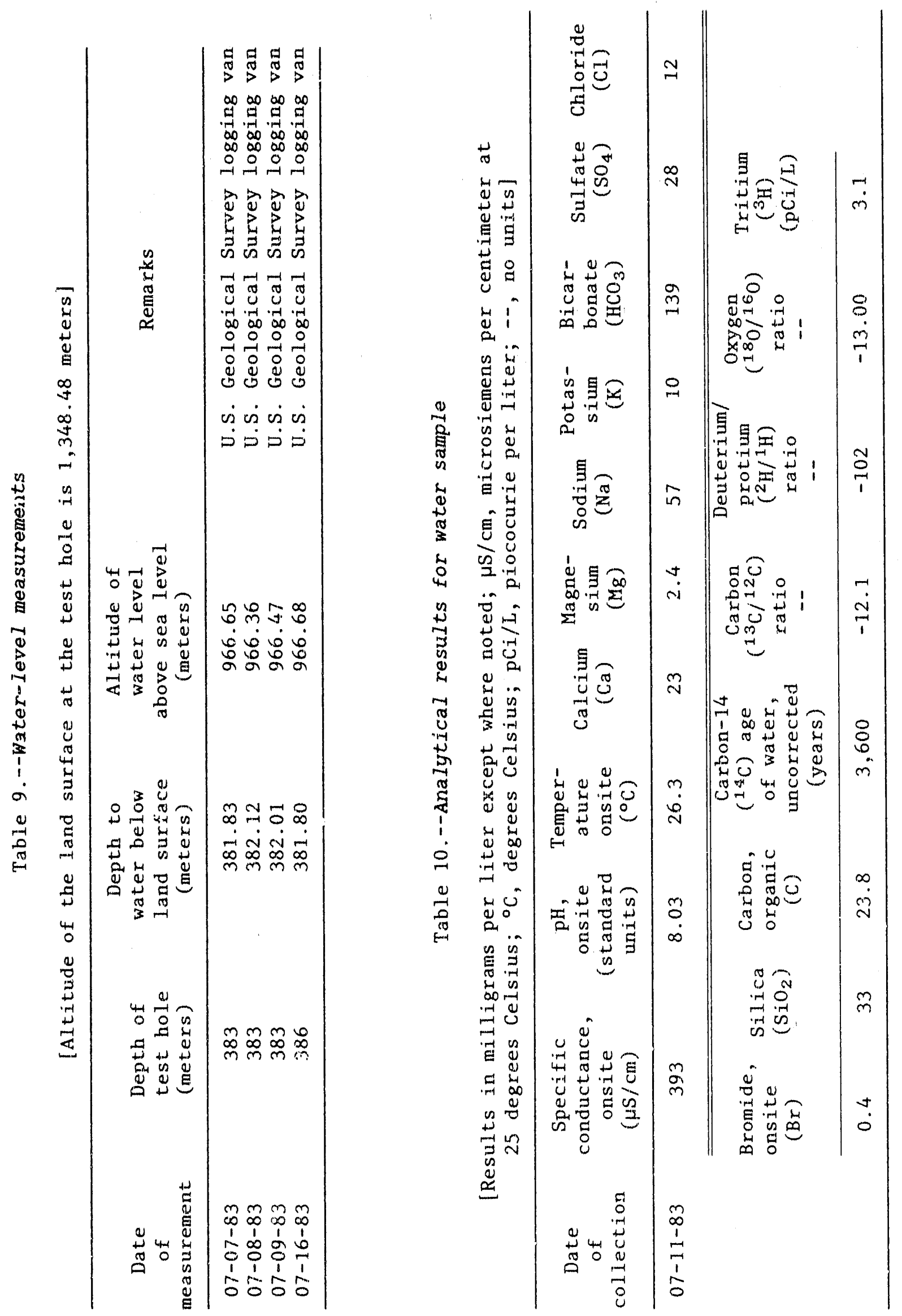


\section{SUMMARY}

This report presents drill-hole, geologic, and hydrologic data for test hole USW UZ-1, the first of two deep, large-diameter (444 mm), unsaturatedzone test holes that were dry drilled into tuff in or near the southwestern part of the Nevada lest Site by using the vacuum/reverse-air-circulation drilling method. Drilling was through the alluvium and through the Yucca Mountain Member, the Pah Canyon Member, and the bedded tuffs of the Paintbrusin Tuff. Drilling was stopped in the Topopah Spring Member of the Paintbrush Tuff. Dry drilling generally was difficult and progressed slowly. This method of drilling, however, enables large-diameter test holes to be drilled without the use of drilling fluids and enables geologic and hydrologic drill-bit cuttings to be collected during drilling.

Use of the vacuum/reverse-air-circulation drilling method to drill large-diameter test holes in the unsaturated zone for the purpose of installing hydrologic instruments has the following advantages: (1) Continuous, representative drill-bit cuttings can be obtained; (2) excessive drying is not a factor, because only a minimal quantity of air flows in the well bore; (3) contamination of drill-bit cuttings does not occur, because no drilling fluids are used; (4) most of the drill cuttirgs and small rock fragments are vacuumed from the borehole which reduces the potential for plugging of fractures and provides a cleaner borehole or air or water injection tests; (5) detection of perched-water or moist zones occurs as scon as the zone is penetrated; and (6) atmospheric contamination can be detected after completion of the test hole by sampling for tracer gas.

Disadvantages of using this method of drilling are that: (1) More extensive equipment and a larger drilling site are needed than for conventional methods; (2) unstable hole conditions are produced by vacuuming, resulting in frequent caving and redrilling; (3) the method is unsuitable for collection of representative hydrologic cores; and (4) in most zones, plugging of the drill bit by mud encrustation of the inner string and kelly hose restricts movement of drill-bit cuttings to the land surface.

Data are presented for bit and casing configurations, coring methods, sample collection, drilling rate, borehole deviation, and out-of-gage borehole. Geologic data for this borehole include geophysical logs, a lithologic log of drill-bit cuttings, and strike and distribution of fractures. Hydrologic data include water-content and water-potential measurements of dxill-bit cuttings, water-level measurements, and physical and chemical analyses of water. Laboratory measurements of moisture content and matric properties from the larger drill-bit cutting fragments were considered to be representative of in-situ conditions. 


\section{REFERENCES CITED}

Gardner, W.H., 1965, Water content, in Black, C.A., ed., Methods of soil analysis: American Society of Agronomy, p. 82-125. NNA.900208.0104

Houghton, S.B., 1959, Vacuum drilling: Mercury, Nev., Fenix \& Scisson, Inc., Office Engineering Division, 32 p. NNA.900208.0105

Richards, L.A., and Ogata, G., 1958, Thermocouple for vapor pressure measurement on biological and soil systems at high humidity: Science, v. 128 , no. 3331 , p. 1089-1090. HQS.880517.2837

NOTE: Parenthesized numbers following each cited reference are for OCRWM Records Management purposes only and should not be used when ordering the publication. 

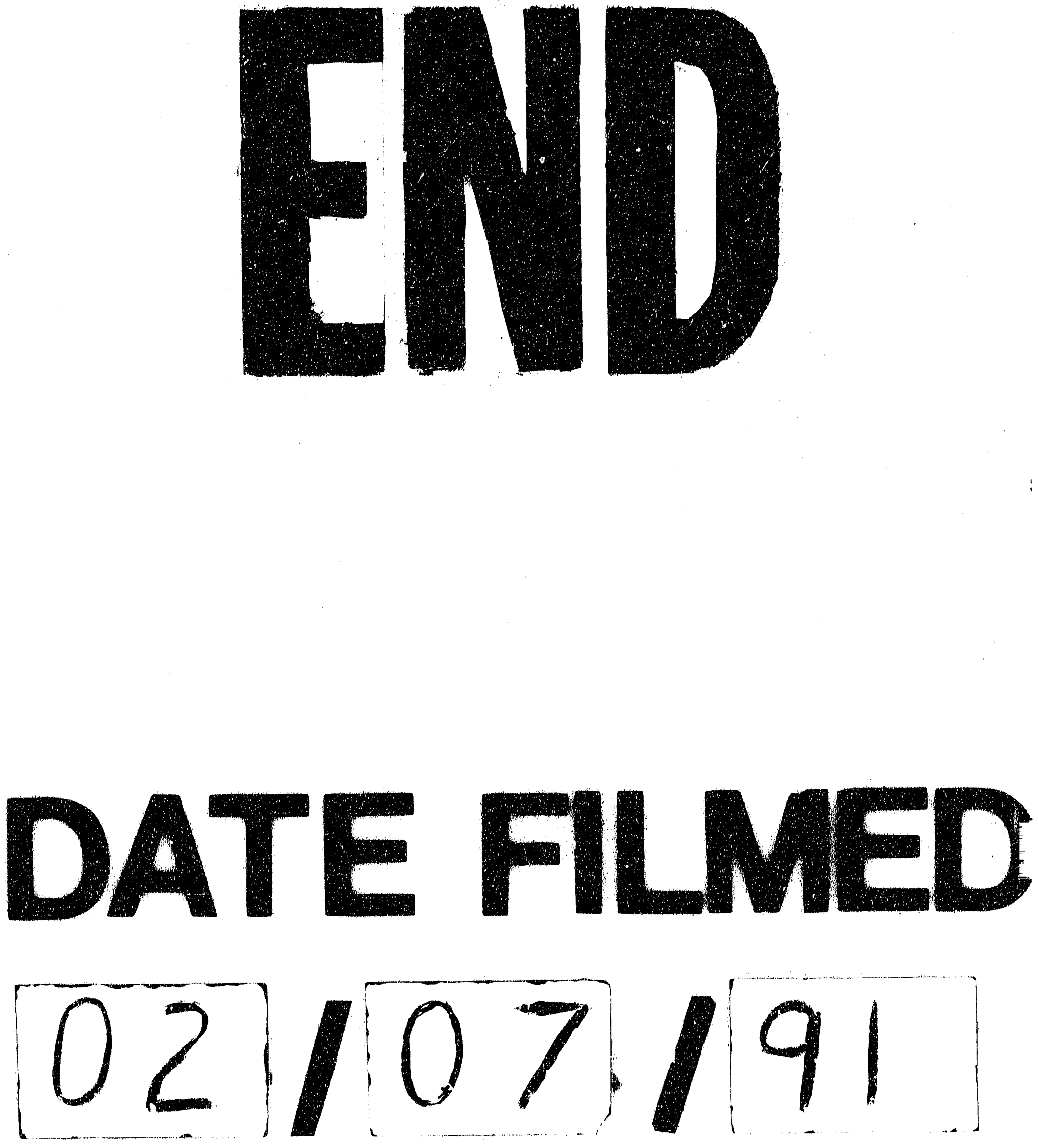


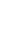

